\title{
QUANDO INOVAR É APELAR À TRADIÇÃO - a condição baiana frente à modernização turística
}

\author{
Edson Farias ${ }^{*}$
}

\begin{abstract}
O objetivo deste artigo é enfocar a tônica depositada na tradição como componente de uma dinâmica sócio-histórica tramada entre distintos grupos em Salvador, mas cujo efeito definiu um modo de modernização concatenado com o cruzamento de identidades de grupos, patrimônios imateriais e arquitetônicos, os trânsitos de imagens e o capitalismo informacional. Tal modo de modernização definiu uma experiência turística marcada pelos usos, da e na cidade, que se fazem do espaço, da memória e das expressões culturais, recursos que são decisivos e, ao mesmo tempo, revolvem um terreno de contradições sociosimbólicas que alimentam a economia simbólica das cidades contemporâneas.

PALAVRAS-CHAVE: inovação, tradição baiana, modernização turística, serviços.
\end{abstract}

Faç̧ões da ciência econômica têm enfatizado, nos últimos anos, o quanto o setor de serviços alterou - e ainda alterará - a feição das estruturas socioeconômicas contemporâneas. O seu peso estaria no aumento da demanda e no valor agregado, com o fornecimento dos serviços no cômputo do sistema econômico. Por semelhante motivo, os serviços também impeliriam reorientações espaciais mais gerais no desenvolvimento de cidades e regiões (Marshall, 1995; Ughetto; Du Terre, 2000). Os comentadores destacam o quanto as metrópoles se redefinem como espaços de dinamização e consumo de tais serviços empresariais e profissionais, sobretudo aqueles relacionados às atividades vinculadas a segmentos da imaterialidade, principalmente os de tecnologias de informação e aqueles de aplicação da pesquisa científica ao conhecimento, além dos financeiros e do entretenimento e turismo (Hall, 1997; Airoldi; Senn, 1998).

* Doutor em Ciências Sociais. Professor de Sociologia do Programa de Pós-Graduação da Universidade de Brasília - UnB. Pesquisador do grupo Cultura, Memória e Desenvolvimento.

Campus Universitário Darcy Ribeiro - ICC - Centro. Cep: 70.910-900 - Brasília - DF - Brasil.nilos@uol.com.br
Embora concentrada no Centro-Sul, em especial no eixo Rio - São Paulo, a estrutura urbanoindustrial e de serviços igualmente adquire contornos mais nítidos em outros polos regionais do país. O estado da Bahia ocupa a primeira posição nos rastros da expansão continuada nas últimas décadas, seja dos segmentos técnico-profissionais inseridos nos business-services, seja no setor de alojamento, o qual se relaciona à expansão acentuada das atividades turísticas e afins (Mesquita; Cerqueira; Almeida, 2004, p. 27). Com 70\% do seu produto interno oriundo do setor de serviços, a capital do estado, ainda que já ostente um razoável aporte dos bussiness services, concentra a mais importante gama nos ramos culturais e turísticos (Almeida, 2004, p. 40-41). Assim, indagamos: até que ponto poderemos compreender como, ao lado do Rio de Janeiro, Salvador consagrou-se como inquestionável destino turístico e endereço brasileiro de cultura e de diversão?

Ganhou fôlego, na última década, a evocação da cultura miscigenada do povo baiano como decisivo componente da atração maior de visitantes nos folhetos de divulgação turística da cidade 
de Salvador. De um modo geral, as peças da publicidade turística assinalam a música e a religião como manifestações da cultura regional, um patrimônio concernente ao talento cultural e artístico local. No trecho a seguir, recolhido de um panfleto de publicidade turística, estão ressaltadas, justamente, a diversidade étnica, as decorrências do pertencimento regional e as propriedades históricas reunidas no sítio geopolítico baiano, como enraizamentos capacitados a se reciclarem em meio às injunções da vida moderna:

Na Bahia, mais do que em qualquer outro lugar do mundo, a cultura é o bem maior do seu povo, patrimônio comum a todos os cidadãos - da capital, do litoral e do interior. Berço da cultura brasileira, aqui está um dos mais importantes polos de produção artística e cultural do país, que preserva, mas sabe agregar sem preconceito valores produzidos pelos movimentos da sociedade contemporânea e suas inovações criativas.

Mística e miscigenada, a cultura baiana é única, diferenciada de todo o contexto nacional, pela combinação de três povos que deram origem à sua formação - o branco, o negro e o índio. Dessas contribuições, reunidas, fez sua marca e criou a personalidade que retrata essa diversidade, tão rica quanto dialeticamente harmônica (Guia Cultural da Bahia, 1998, v. 5, t. 1).

Em razão da época em que foi elaborado e posto em circulação - a segunda metade dos anos noventa, momento de aplicação de um plano tenaz de divulgação turística da Bahia -, o texto chama a atenção porque deixa a inovação na contrapartida do engajamento dos símbolos e práticas lúdico-artísticas populares, adornados pela aura da "cultura baiana". Vale lembrar que publicidades dessa natureza evidenciam como, nas políticas públicas capitaneadas, em grande medida, pelo grupo carlista, ${ }^{1}$ foram executados projetos que

${ }^{1}$ Hegemônico no estado da Bahia, entre os anos de 1990 e 2005, o grupo teve em Antônio Carlos Magalhães o núcleo de alianças que introduziram em novas condições facções das elites oligárquicas do Nordeste no cerne dos setores de comando político-institucional do Estado nacional, sobretudo após o advento da Nova República, com a fundação do Partido da Frente Liberal, em meio ao contexto da redemocratização do país. Desde a fase dos governos militares, adaptou-se o perfil tecnocrático assumido pelas instâncias estatais de poder às soluções de pressões na nomeação para cargos estratégicos de nomes integrados ao escopo dos seus escolhidos ou com a montagem de uma grande bancada legislativa dotada de amplas bases eleitorais municipais e estaduais, porém com repercussões decisivas nas esferas federais. Base controlada mediante instrumentos de represamento e distribuição de recursos capazes de tornar possível a elei- sintonizavam modos de vida e pautas de desenvolvimento socioeconômico pela tônica depositada no vínculo entre tradição e inovação. Desde a década de 1970, em Salvador, na interface com ramos da iniciativa privada, com vistas à exploração turística, são executados projetos para as áreas de diversão e turismo, num cenário social em que a gama de prestação de serviços atesta a importância institucional do entretenimento. Isso ocorre não apenas na geração de lucros, mas igualmente na ressignificação de memórias e mesmo do sentido de práticas nas quais se intersecionam traços de gênero, classe, etnia-raça como teores étnico-históricos que se tornam insumos decisivos para a economia, definida pelo comércio de informações.

Neste artigo, desenvolvemos o argumento de que a dinâmica histórica caracterizada pela mútua referência entre tradição e inovação, na modernização turística em Salvador, entre as décadas de 1930 e 1990, ocorreu na medida em que saberes e poderes relativos, respectivamente, às elites políticas e intelectuais e também às lideranças religiosas e lúdico-artísticas estiveram crescentemente em interdependência sociofuncional. Enfocaremos a maneira como a tradição se torna um objeto nas tramas sociodiscursivas que envolvem esses grupos e se constitui numa moldura ideológica. Portanto, não será abordado o plano empírico-analítico específico das práticas lúdico-artísticas, religiosas, populares e negro-mestiças, mas tão-somente como elas são posicionadas no status de ícones baianos. O percurso de exposição e análise está dividido em três seções. Na primeira, situamos o debate teórico a respeito da correlação entre tradição e modernização nas teorizações sobre a modernidade, na teoria sociológica contemporânea, com a finalidade de especificar o problema da modernização turística. Em seguida, a atenção é dirigida para os deslocamentos na concepção de tradição baiana e, nela, a integração dos elementos da cultura popular local. Finalmente, atenta-se para as condições de possibilidades sócio-históricas do recurso discursivo voltado para a narrativa da tra-

ção ou não de candidatos ao executivo e ao legislativo (Dantas, 2006). 
dição baiana (com os apregoados dotes culturais e artísticos de sua gente), na implementação de projetos de desenvolvimento do comércio cultural e de diversão, principalmente no tocante aos serviços turísticos. A ênfase recai no tipo de aliança estabelecida entre poder público, facções de intelectuais e setores da cultura popular.

\section{QUAL TRADIÇÃO? QUAL MODERNIZAÇÃO?}

Se tomarmos a globalização à maneira de uma grande narrativa, cujo relato tem por objeto os movimentos e situações que compõem o entrelaço dos fluxos de capitais com redes de produção e comunicação, os quais incluem também, em seus meandros, as tramas dos crimes e das instituições internacionais, dos aparatos militares supranacionais e das organizações não-governamentais, além das religiões transnacionais e dos movimentos de opinião pública (Castells, 1999, p. 353), o que tem sido recorrente, em alguns dos intérpretes do mundo contemporâneo, é a ênfase na sintonia hoje estabelecida entre uma extraterritorial sincronização global e as cada vez mais evocadas alianças fundadas no pertencimento e na auto-imagem de base local-afetiva. Para Zigmunt Bauman, a pujança adquirida pelo paradigma da velocidade joga um papel decisivo nessa cena atual, já que, diante dela, a dissolução e a flexibilidade se impõem como critérios incontornáveis a pessoas, grupos e entidades. Em meio ao turbilhão do fremente trânsito de tecnologias, gente e idéias, teriam ido à ruína as referências mais duradouras. Afinal, no "admirável mundo novo das oportunidades fugazes e das seguranças frágeis, as identidades ao estilo antigo, rígidas e inegociáveis simplesmente não funcionam” (Bauman, 2005, p. 33). A diluição da tradição seria uma das conseqüências imediatas do estágio líquido da modernidade, ${ }^{2}$ caso se comparti-

2 A concepção de "modernidade líquida" em Bauman (2001) se funda na premissa de um estágio do processo moderno erguido à sombra dos escombros resultantes do prurido moderno de a tudo destilar, período em que se teria coletivizado o que fosse monitorado pelos dispositivos de controle de pureza acionados pelo Estado em conjunto com a ciência. Viveríamos, ao contrário, em lhe ainda o argumento de Bauman. Na condição de um horizonte interpretativo, fundado na exemplaridade do passado, pelo qual se dá a tradução daquilo que é contingente pelo estável, a tradição soçobraria arrastada pelos fatores de desencaixes espaciais e temporais, para os quais o apelo ao ligeiro é o sinal de impaciência diante de toda e qualquer estável profundidade social e existencial.

A nosso ver, tal conclusão parece igualmente apressada, na medida em que não considera justamente como os conceitos, se os tivermos como figurações, estão inseridos nas propriedades das interdependências nos seus contingenciamentos históricos. Argumentamos, então, estar o significado da tradição em consonância com o arranjo e a correlação de forças sócio-humanas que o reivindiquem ou descartem. A esse respeito, mostram-se sugestivas as situações destacadas pela rubrica do turismo. Isso porque parece, ao estar sintonizado aos trânsitos planetários, o complexo de atividades turísticas é evocado como um dos ícones da globalidade. Diz respeito a uma das faces decisivas da característica atual da economia-mundo capitalista, a de priorizar a diversidade no implemento da sua expansão e remuneração, justamente porque estreita vínculos com elementos inseridos nos catálogos de bens intangíveis, identificados com tradicionalidades regionais ou nacionais, muitos dos quais dotados de aportes étnicos, a exemplo de sítios do patrimônio histórico. Atentos a tal conluio, Urry e Lash postulam ser o turismo revelador de um outro padrão de cidadania notabilizado pelo "cosmopolitismo estético". Ou seja, a experiência dos indivíduos ambientados nos nichos móveis do mundo moderno seria a de pessoas dotadas de recursos culturais e sensoriais para avaliar a diversidade dos seus atos e dos lugares

uma época na qual teria ganhado vulto a desconfiança generalizada para com a justificativa do código de ética moderno do "impulso para adiante", assentado na promessa da regulação sem contenção e no primado da transparência total. Nessa tocada, entende o autor, a lúbrica atmosfera do interesse pela diversidade se propagou, numa valoração ávida da “desordem” do mundo. A nostalgia para com a segurança se fez crescentemente mais um estilo ao sabor das ondas sucessivas efêmeras de homens e mulheres bem acomodados à "infixidez de sua situação, suficientemente atrativa para prevalecer sobre a aflição da incerteza.” 
nos quais se põem a circular e a conhecer (Lash; Urry, 1994, p. 266). Fica-nos a dúvida: de que tradição e de que cosmopolitismo estamos tratando?

Parece-nos incontornável estabelecer um quadro sumário acerca da discussão sobre a tradição na teorização sociológica atual e, com isso, precisar a qualificação teórico-analítica que faremos do material empírico tratado na segunda parte deste artigo. Delimitarei o debate recorrendo à polarização tradicional versus moderno e, a respeito, priorizo a formulação de Giddens sobre o contexto de uma sociedade póstradicional no estágio da modernização reflexiva. A opção atende ao objetivo de verificar como tradiçãoe inovação são, a princípio, dispostas em terrenos semânticos e ideológicos opostos.

O implemento da modernidade introduz, para Giddens, uma substituição decisiva no tema do controle do tempo. Para ele, a tradição corresponderia a um controle do tempo mediante a combinação entre conteúdo moral e emocional na organização da memória coletiva, istoé, no modo ativo e interpretativo como, ritualmente, o controle coletivo pressiona os indivíduos no recolhimento e reciclagem das lembranças. Os guardiões da tradição estariam investidos, portanto, da tarefa de controle, ao estarem entronados na autoridade garantida por normas enraizadas na repetição de um originário passado exemplar. Oposta a esse procedimento, afirma o autor, na modernidade, a compulsão se faz sem o respaldo de tal horizonte fixo, assentado no domínio dos deuses, e a rotina tende a se esvaziar caso não intervenham fórmulas institucionais de reflexividade. Enfim, sustenta ele que, nos contextos pós-tradicionais, as atividades cotidianas se encontram abertas às escolhas e decisões humanas, que podem influenciar reflexivamente aquilo que lhe diz respeito. Também o meio natural é transfigurado pela intervenção humana no compasso da intensa socialização. De acordo com o entendimento do autor, esse processo produz o deslocamento da segurança ontológica (tácita no contexto tradicional) para o centro do problema existencial e histórico na modernidade. E isso decorre de um encadeamento que se manifestaria no caráter descentralizado no trato com o conhecimento, pela sua desincorporação e pela possibilidade de sua correção, mas também em razão da tradução do acúmulo do conhecimento em especializações. O que, conclui, resultaria instauração da confiança em sistemas abstratos não gerados por meio de sabedoria esotérica, e sim pela interação da especialização com a reflexividade institucional.

Durante a hegemonia do Ocidente, lembra ainda Giddens, a ciência se fixou como fonte monolítica de verdade, mas suas consequências não programadas acirraram a especialização em distintos domínios de experts, em concordância com o aumento exponencial da reflexividade. E, se a competência técnica do especialista está encerrada no seu âmbito de atuação, força-se a promoção de estilos de vida e meios de confiança calcados em sistemas abstratos que relacionam "outros ausentes”, mediante a triagem de informações. Não resta dúvida de que esse contexto surgiu sobre a esteira das unificações implementadas tanto pelo Estadonação quanto pelo capitalismo. Mas, segundo o autor, ela é marcada pelos processos concomitantes da globalização e da busca de contextos de ação mais tradicionais. A fase da "modernização reflexiva" alteraria o equilíbrio entre tradição e modernidade. Impõe-se o predomínio da "ausência" sobre a "presença", e a "intimidade" se torna o palco das descentralizações e interrogações cruciais. A saber, a destradicionalização se propaga e introduz o lugar da tradição em um universo competitivo de valores plurais. O problema posto, desde então, é aquele do desengate promovido pela extensão planetária desse complexo. Alternativas à situação instaurada se apresentariam seja nos enraizamentos na tradição, seja no alheamento hostil do "outro". Igualmente se poderia tender para o discurso ou o diálogo ou, em oposição simétrica, voltar-se à coerção e à violência (Giddens, 2001, p. 21-97).

A par desses argumentos, as consequências da difusão global das instituições da modernidade seriam os cada vez maiores impactos dos processos de mudança intencionada no cotidiano do planeta afora, em consonância com a extensão sem 
precedentes das interdependências. Segundo Giddens, algo assim altera por completo a tendência, prevalecente até então na história da modernidade, de restituir a tradição no instante mesmo em que a esvaziava. Nesse sentido, o aumento generalizado da condição moderna imporia ao juízo a vicissitude do aumento do conhecimento, isto é, o risco se tornaria fonte de incerteza e, ao mesmo tempo, um meio para manter o futuro sobre controle. Com isso, a reflexividade estenderse-ia pela experiência pessoal, mas também invadiria as dinâmicas institucionais, armando-se um cenário em que a experimentalidade baniria de vez o "prometeismo" do progresso, contido na teleologia definida pela devolução da existência humana a um patamar pleno de segurança. Ao ser a introdução do novo, como abertura do presente para o futuro, o exercício de inovar se tornaria um fator básico na geração de saídas pessoais e institucionais para a recriação existencial e sistêmico-institucional nessas condições.

Para os objetivos deste artigo, é de todo interesse a proposição defendida por Giddens sobre a inserção do lugar da tradição nas disputas entre as diversas possibilidades discursivo-interpretativas, em uma espécie de mercado do sentido global. Valiosos ingredientes explicativos e interpretativos são fornecidos para a observação de como os princípios e meios de orientação das condutas se ajustam ou não ao tipo em vigência de seleção e sincronização dos elementos padronizados como propriedades de um sistema social. Ao mesmo tempo, são deixadas importantes pistas para a reflexão sobre como podem ser ajustadas inovação e tradição. Contudo são negligenciados dois aspectos no argumento do autor, os quais ocupam papéis centrais na análise aqui desenvolvida. De um lado, do ponto de vista ontológico e estrutural, passa ao largo a indagação se é a polaridade tradicional versus moderno imanente à espinha dorsal do discurso da modernidade, logo, constituindo um dos seus pilares de sustentação. Já, de outro, mas angulado a partir da possibilidade de averiguação histórico-empírica das relações, processos e estruturas sociais, desconsidera-se a possibili- dade de a tradição compor o ritmo mesmo da cadeia de inovação, própria à programação modernizadora, tanto como categoria a priori do entendimento, quanto como modo interpessoal de comunicação, a depender das características em que essa última se desenrola. Com o intuito de pavimentar o caminho da correlação entre turismo e espaço sócio-urbano em Salvador, façamos uma sumária visita às duas alternativas.

Inicialmente, tomamos por base algumas das linhas sobre o discurso filosófico da modernidade, em Habermas. Para esse autor, a atitude reflexiva perante o costume consistiria no caráter inovador por excelência da modernidade. Quer dizer, a modernidade corresponde ao procedimento pelo qual a autoridade do passado, inscrita nas categorias do entendimento, mobilizadas na avaliação da seqüência dos eventos e dos limites da experiência, é levada ao lugar do pensado e se torna alvo das interlocuções. Isso no instante mesmo das tomadas de decisão frente ao desenrolar incessante dos acontecimentos. Quer dizer, no momento em que os universos de significados são mobilizados nas práticas dialógico-argumentativas, a partir dos domínios institucionais da memória, reguladores dos fluxos das lembranças e dos esquecimentos. As situações de crise informadas pela memória tornam-se, então, fatores não apenas de prosseguimento, mas o seu aprendizado implica também a autocorreção ou alteração drástica no curso das condutas.

Indo um pouco mais amiúde na trama da genealogia do significado filosófico do moderno, realizada por Habermas, na atmosfera aspirada na Europa Norte-Ocidental do século XVIII, o autor nos mostra como prevalece, naquele contexto, a distinção entre os "tempos modernos" e o conceito cristão de "novos tempos". Se esse último descreve um tempo ainda por ser instaurado, a idéia de tempos modernos tem, na sua natureza secular profana, a certeza quanto ao já iniciado futuro. Ou seja, o moderno consistiria na abertura mesma para o novo e, portanto, corresponderia a uma cisão de época cuja radicalidade rompe com a modelação (o passado, a tradição) e se reconhece como o novo tempo ou o tempo do novo. Desse modo, incorporada à 
filosofia na obra de Hegel - A Fenomenologia do Espírito-, a noção de "espírito do tempo" (Zeigeist) retém uma tensão estrutural-ontológica no percurso auto-configurativo do espírito. Assim, os "novos tempos" são dotados, ou melhor, constituem-se na consciência do aceleramento do ritmo do próprio tempo e possuem a consciência da mudança em que o futuro não mais é reduzido à mera projeção do passado, porque se trata de algo heterogêneo, até mesmo hostil a esse último. A tensão traduz o enfrentamento entre a plenitude do existente e a suspeita oriunda da indeterminidade do desconhecido.

A julgar pelo sumário dessa descrição, em sua radical advertência de separação e oposição diante dos parâmetros fornecidos pelo passado, o enunciado do moderno introduz, ao mesmo tempo, a complementaridade e a contradição com o antigo, tanto como plataforma de sustentação do discurso acerca da primazia do novo, como também na condição de termo de mediação disposto na composição seja da idéia de moderno, seja na de tradição. Em síntese, a modernidade como princípio procedimental orientado para a avaliação contínua dos consensos cristalizados como fundamentos das atitudes humanas, se implementa na constância da apresentação de um passado ao qual deve se opor. O imperativo de tal critério insere, incontornavelmente, os eixos tradicional e moderno como pólos indissociáveis da modernidade, que se realiza na cumplicidade ontológica do ser com o devir, pois identidade e mudança intencionada formam, respectivamente, as bases do concerto entre as lógicas culturalista $\mathrm{e}$ desenvolvimentistas (capitalismo e industrialismo), mesmo quando ambas se opõem entre si, na história da condição moderna. Por lógica culturalista denominamos a coordenação da compreensão social cujo ideário em pauta é o reconhecimento da dignidade da estima humana, sobretudo os valores que balizam a consciência dos indivíduos e, portanto, concorrem para a sedimentação de significados intersubjetivamente tecidos e transmitidos intergeracionalmente. Ao falar em lógica desenvolvimentista, a princípio, faz-se referência às coordenadas com efeitos sobre a compreensão soci- al, comprometidas com o ideário do aperfeiçoamento técnico-moral permanente, mediante a crença na faculdade cognitivo-instrumental de mobilizar meios no implemento do acúmulo de conhecimentos que se convertem em transformações qualitativas nos ambientes e nas percepções humanas.

Desse ponto de vista, torna-se interessante acompanhar o assinalado intercruzamento entre tradição e inovação - considerando o quanto um e outro, respectivamente, são representativos de cada uma dessas lógicas. O nosso argumento é de que os processos sintetizados na categoria de modernização turística são particularmente exemplares a respeito. Em linhas gerais, a noção de modernização consiste no desenvolvimento da tendência da civilização moderna de acelerar intencionalmente o ritmo dos acontecimentos; civilização na qual o eixo de sucessão dos acontecimentos inscritos nas redes de interações humanas e seu relacionamento com o entorno tem por motor a crença tanto na otimização máxima dos recursos simbólicos e materiais quanto no aperfeiçoamento permanente como fórmulas para a edificação do tempo da prosperidade. E tal incremento faz dueto com o relevo posto no desvelamento da naturalidade das contingências e, também, com a ascensão das reivindicações por auto-realização como finalidade da elaboração de projetos individuais de mudança das condições e dos estilos de vida. Nesse sentido, parece ser adequado detectar como o ímpeto decorrente da necessidade de oferecer suporte material à sensibilidade devotada à mutação permanente está na contrapartida do vertiginoso implemento das redes e dos meios de transportes e de comunicação e expressão, considerando, ainda, que ambos se inserem como instrumentos para a dissolução do isolamento como mecanismo de construção dos horizontes sociosimbólicos (Leed, 1989; Sack, 1992).

Podemos, assim, chamar a atenção para o fato de que, para a idéia de modernização turística concorre o leque de fatores práticos e institucionais, acoplado a essa dinâmica sociocivilizatória da modernidade, em que se ajustam evocação da mudança e apelo ao bem-estar individual. Logo, é fundamental qualificar a modernização. Parece-nos ra- 
zoável propor que a modernização turística sintetiza interdependências sociofuncionais alargadas (nas dimensões socioeconômica, política, simbólica e cultural, mesmo afetiva), nas quais vicejam hierarquias e controles concatenados simultaneamente ao movimento do capital eà racionalização sociocultural (Santos, 1994, p. 31-34). Ao mesmo tempo, essa teia sócio-humana também existe no teor multifacetado de agentes, fatores e realidades que marca o formato e o compasso da processualidade modernizadora turística. Desse modo, a polaridade composta pelas noções "próximo" e "distante" desliza para outro plano conceitual e torna pusilânime o postulado de um movimento tão-somente homogeneizador ou, ao contrário, de pura constatação quanto à proliferação de diferenças, num mosaico planetário. Embora diga respeito à sistematização institucional orientada pelo princípio da mudança intencionada dos móveis e patrimônios étnico-históricos e geográficos de uma localidade, talvez o mais adequado seja considerar a trajetória de formatação dos lugares de entretenimento e turismo sob a ótica do entrecruzamento de modalidades de aprendizado, educação dos afetos, dependências mútuas e interpenetrações funcionais, não restrita à ação de sistemas colonizadores sobre o mundo-da-vida dos lugares balizadores, mediante os fundos coletivos de conhecimento das experiências primeiras dos agentes, desterritorializando práticas e símbolos. Entende-se que tal processo modernizador é convergente com os elos forjados nas negociações entre as singularidades históricas e culturais dos espaços locais e os critérios dos sistemas de peritos, num encaixe de dimensões territoriais indefinidas, proporcionando o incremento de esferas especializadas na produção cultural do espaço do entretenimento-turismo, com suas paisagens e os tipos de uso possíveis em seu raio de alcance.

\section{A “CULTURA DO POVO" E O DESENVOLVI- MENTO TURÍSTICO NA BAHIA}

Se o problema teórico aqui enfocado compreende a confluência entre as lógicas culturalista e desenvolvimentista da modernidade na ambiência do entretenimento-turismo, a cidade de Salvador fornece insumos decisivos à análise e à interpretação, privilegiados em razão do lugar reservado aos modos e meios de vida rubricados como tradicionais nas cadeias de produção e consumo de bens de diversão e lazer. Portanto, o tratamento analítico de alguns materiais empíricos relativos à experiência histórica da Bahia no século XX responde à meta de observar em que medida a noção de modernização turística corresponde a um processo de reavaliação dos limites, em razão da aceleração dos trânsitos em escala planetária. Nesta seção, iremos nos voltar para o ajuste entre práticas lúdico-artísticas e religiosas e modernização turística, mas dando atenção às tramas sociodiscursivas em que a idéia de tradição baiana se insere como categoria de pensamento e representação coletiva, em especial por se tratar de um meio de comunicação interpessoal, no arranjo social em que, no andamento histórico, o comércio de signos e espaços salta à frente na coordenação das relações sociais em determinadas condições sócio-históricas.

Para os interesses deste artigo, optou-se pelo esquema de análise configuracional das interdependências sociofuncionais como dinâmicas de pressões mútuas entre as pessoas (Elias, 2001, p. 111-112), na medida em que se priorizam os movimentos pelos quais o turismo é destacado como alternativa de desenvolvimento para a região, nas propriedades negociadas e na própria natureza dessas negociações. Sabe-se que essas últimas envolvem produtores e intermediários culturais, administradores, elites políticas e segmentos empresariais em torno do enlace informação e identidade, economia e cultura, dinheiro e reconhecimento. Sob esse ponto de vista analítico, retomamos um argumento desenvolvido em outra oportunidade (Farias, 2007). ${ }^{3}$ Nele, propo-

${ }^{3}$ Os materiais empíricos aqui mobilizados decorrem das respectivas pesquisas A Invenção da Bahia como Tradição na Modernização Baiana (2001-2003) e a Montagem da Sistemática de Órgãos de Cultura no Estado da Bahia (2004-2005). Agradeço, em especial, aos estudantes Fernando Rodrigues, Rosevel Silva e Tiago Lourenzo, bolsistas do Programa PIBIC/UFBa-CNPq, pela colaboração valiosa no levantamento das fontes. Ambos os estudos compuseram o escopo do programa de pesquisa "Ressignificações de Domínios de Memórias em Contextos de Modernização”, implementado entre 2001 e 
mos que o avatar da narrativa sobre a tradição baiana esteve em consonância com as vicissitudes experimentadas pelo leque de grupos dominantes regionais, no momento em que o processo de centralização estatal nacional os colocou em posição inferiorizada nas linhas de comando concentradas no centro-sul do país, desde o terço final do século XIX. Mas a tradição estará, na sua ascendência como auto-imagem regional, na contrapartida do incremento da referência simbólica recíproca entre camadas dominantes e subalternas. Isso por fornecer meio de expressão ao sentimento de pertencimento coletivo que se introduz também como propriedade estrutural das práticas de outros grupos, algo capaz de subsidiar novas táticas realizadas por agentes com menor acúmulo de capital social. Agentes que assim poderão se apropriar dos resultados da estratégia de distinção de camadas dominantes em acentuar a transigência como valor ancestral, mas circunstanciados por suas posições e condições de classe. Daí seguemse duas tendências. De um lado, as facções dominantes aplicam esforços - calcados no recurso do discurso sobre a antecedência da Bahia na formação dos valores nacionais -, visando a integraremse nos pólos decisórios da República. De outro, a consequência não programada de tal aplicação consiste na exigência de estender suas bases de legitimidade, o que transportou práticas, símbolos e instituições dos segmentos populares para as instâncias conspícuas da representação regional. Cada vez mais, eles são referidos como elementos constituintes da chamada "Bahia tradicional”, núcleo da "mística brasilidade lúdica".

Ao mesmo tempo, impõe-se definir uma periodicidade para realizar a sociogênese pela qual pretendemos descrever e qualificar as interdependências sociofuncionais em que se realizou tal convergência sócio-histórica. ${ }^{4}$ No levanta-

2004, no grupo pesquisa sobre Cultura, Memória e Desenvolvimento, o qual estava, na ocasião, vinculado ao programa de Pós-Graduação em Ciências Sociais da Universidade Federal da Bahia.

${ }^{4}$ Realizado no Arquivo Público do Estado da Bahia - durante os anos de 2001 e 2006 -, o levantamento abrangeu o período de 1910 a 2006, concentrando-se nos os jornais de maior periodicidade nesse intervalo: Impressa Oficial, $A$ Tarde, Diário de Notícias, Correio da Bahia e o Imparcial. mento documental realizado, os achados de pesquisa permitiram concluir, sobre a década de 1930, como aquela em que ocorreu a institucionalização da intervenção regulatória do Estado na economia, obedecendo a uma tendência de ampliação da presença desse ordenamento no conjunto da sociedade. Então, na contrapartida do desenrolar de alterações voltadas à "racionalização do serviço público" estadual, em sintonia com processo afim na esfera federal, sob égide do governo Vargas (Lamounier, 1992, p. 41-42), ocorreram iniciativas governamentais cujo objeto era o desenvolvimento de estudos preliminares dos serviços administrativos existentes nas secretarias de governo e na elaboração de um plano de reorganização geral dos serviços da Secretaria de Fazenda e Tesouro, além das demais secretarias. O que mais nos interessa é que, igualmente, essa foi a ocasião das primeiras indicações de incentivos à cultura artística e ao turismo. No que toca ao último aspecto, é oportuno observar o Relatório das Atividades da Administração Pública no biênio 1938-1939, apresentado pelo Interventor Landulpho Alves, pois nele lemos o seguinte:

As condiç̃es que a Bahia oferece para o grande turismo, já pelo seu clima excepcional, já pela variedade sem par de suas paisagens, pela riqueza de suas antiguidades, desde as arquitetônicas, às ligadas aos usos, costumes tradicionais, estão a indicar a alta importância que assumirá, em futuro remoto, o turismo no Estado.

Cumpre, para isto, aparelhar-se a Capital com o hotel e o restaurante modernos, com o "cassino", com os centros de diversões, com os meios de transportes adequados.

Na falta de recursos para atender a todos esses fatores simultaneamente tem, entretanto, o Governo encaminhado a solução de alguns deles, tais como o aparelhamento para restaurante, o "cassino", o melhoramento das estações balneários, o auxílio ao Touring Club do Brasil. ${ }^{5}$

Já nesse documento, fotos e textos-legendas destacam os "aspectos turísticos da Bahia”, situados em Salvador, à maneira do Claustro, do Campanário e da Sacristia da Igreja do Carmo; o interior da Catedral de São Francisco; o restaurante Lido. Ainda, outras fotos e textos ressaltam estações hidrominerais (Itaparica e Cipó), sublinhando a ${ }^{5}$ Fonte: Imprensa Oficial, 1941. 
importância da estrada então sendo construída, que ligava a cidade de Cipó à de Paulo Afonso, que, afinal, poria a capital estadual "em contato direto com a grande cachoeira" e ela seria de "grande interesse para o turista nacional, como para o estrangeiro, que terão no percurso de 7 a 8 horas de rodovia a vencer entre os dois extremos, a Estação Hidro-Mineral de Cipó, onde encontrarão condição de repouso e conforto que, certo, não dispensarão”. O mesmo Interventor não deixa, porém, de enfatizar o quanto o apoio do governo federal se fazia necessário para sanar o problema de intensificação da obra, pois

certo como é que, resolvido, poder-se-á ter nele uma grande fonte de renda ao lado de apreciável meio de propaganda do Brasil no estrangeiro, sobre ser igualmente, um modo de fazer com que a Bahia seja mais conhecida dos filhos de outros Estados no pensamento do Brasil conhecer a si mesmo. ${ }^{6}$

Não há qualquer dúvida a respeito da incipiência seja do interesse governamental em relação ao turismo, seja dos seus esforços no ordenamento em direção ao setor cultural. O que mais importa é notar, porém, o despontar da tessitura discursiva interna ao Estado, a qual delineara ambos como objetos a merecerem atenção. No decorrer da década seguinte, novas iniciativas se sucederam nessa direção, a exemplo da criação da Inspetoria de Museus e Monumentos, interna à proposta de montar um "sistema de órgãos culturais” (abrangendo bibliotecas públicas, teatros e outros equipamentos), o qual naquela ocasião deveria estar diretamente concatenado ao desenvolvimento do sistema escolar público no Estado. Mais ainda: na mensagem do então governador Octávio Mangabeira, identificava-se as fragilidades a serem debeladas no sentido de tornar Salvador capaz de maximizar seus dotes turísticos, e as alternativas estavam relacionadas à implantação de equipamentos e serviços artísticos, culturais e de lazer:

A cidade do Salvador, tão digna, por todos os títulos, de que tenhamos por ela maiores extremos, é de fato uma cidade que, pelos seus encantos

\footnotetext{
${ }^{6}$ Fonte: Op.cit., p. 13.
}

naturais, e outros predicados que a distinguem, pode e deve tornar-se agradável para os que nela habitam, e, com vantagem, adaptar-se ao turismo, nacional e internacional.

Para tanto, porém, é indispensável que seja dotada de elementos, por assim dizer, de instalação, sem os quais o desconforto exclui o bem-estar, e será talvez impróprio, ou até contraproducente, que se desenvolva em seu favor a propaganda turística, de que muitos lugares do mundo tiram grande partido.

Uma cidade com serviços deficientes, para não dizer lastimáveis, de iluminação, de abastecimento de água e em geral de saúde pública, e igualmente de assistência; uma cidade mal tratada, na limpeza, no calçamento das ruas, na manutenção dos jardins, e onde o acesso a pontos pitorescos se apresente, não raro, difícil, quando não mesmo impossível, ou pelo menos, incômodo; desprovida de hotéis, restaurantes, bares ou cafés, cinema, teatro - não basta que tenha bela a natureza, templos, antiguidades, tradições, para que proporcione aos seus moradores, sobretudo aos seus visitantes, porventura habituados ao conforto da vida moderna, o agrado, os atrativos, que a façam realmente sedutora, como convém, principalmente ao turismo. ${ }^{7}$

A aproximação entre a implantação de um sistema de órgãos culturais e a otimização da vocação turística da capital deixa entrever a aliança que, aos poucos, será estabelecida entre ambos, como que definindo um eixo sobre o qual a execução de projetos no setor cultural teria por contrapartida indireta o incremento nas atividades turísticas. Nesses rastros, no governo de Octávio Mangabeira, são desapropriados terrenos em torno da célebre Praça do Campo Grande - cenário da reverência à luta da independência estadual -, tanto para erguer o Teatro Castro Alves quanto para instalar o Hotel da Bahia. Por outro lado, a conjugação de um e outro plano estão, naquele instante, inscritos nos esforços de destacar a cidade "que se preza de ter sido berço da nação”. ${ }^{8}$ Dava-se, desse modo, a paulatina triangulação entre turismo, cultura e ordenamento público estatal, sendo o último uma espécie de guardião e promotor dos recursos artísticos, culturais, históricos e arquitetônicos do Estado, os quais poderiam ser realçados como fatores de atratividade de visitantes nacionais e internacionais.

Apenas na década de sessenta, no entanto,

7 Fonte: Relatório de Atividades do Governo Octávio Mangabeira, 07/11/1948.

${ }^{8}$ Fonte: Fala do governador Octávio Mangabeira, 10/06/ 1949, p. 25. 
os enunciados inerentes ao ordenamento estatal qualificam de "baiana" a cultura tornada alvo do interesse do poder público. Sobretudo, encontramos a primeira referência às "tradições" da cultura da Bahia em 1963, no escopo do relato que sintetiza o governo Juracy Magalhães. O trecho a seguir é notável pela tônica posta no que seria peculiar à singularidade local-regional (ou seja, os ditos "valores baianos”), dispondo-se a última como fator de classificação, acomodação e reconhecimento de peças e manifestações inerentes ao "ser da Bahia":

Procurei ser fiel, de outra parte, às tradições de cultura da Bahia. Desse modo, esteve presente o Governo em todos os movimentos de finalidade cultural que se verificaram entre nós; prestigie os artistas bahianos, criei o Museu de Arte Moderna da Bahia, a quem doei, após a sua restauracão, o Solar Garcia d'Ávila, na entrada da avenida de Contorno - hoje Lafayete Coutinho Museu que se tornou instrumento precioso do intercâmbio cultural e artístico da Bahia; dinamizei o Arquivo Público, como o Museu do Estado, onde têm sido realizados cursos e feitas publicações merecedoras de destaque, entregues, um como o outro, a valores bahianos estranhos à vida partidária; foi criado o Conselho do Patrimônio Histórico e Artístico da Bahia (...).

No mesmo documento, à maneira da atitude dos seus antecessores imediatos, também o governador Juracy Magalhães deixa o tema do turismo contíguo ao panorama cultural. Nessa ocasião, no entanto, ele lamenta as consequências nocivas da negligência por parte do poder legislativo aos propósitos de incrementar das atividades turísticas. Embora evidencie seu desapontamento, o então chefe do executivo estadual faz questão de mencionar o interesse alargado mundo a fora pela "vida baiana", incluindo aí, pela primeira vez, a "sensibilidade da nossa gente":

Pena é que a Assembléia não tenha aquiescido na criação do Serviço de Turismo do Estado, que lhe propus e que nos permitirá, à Bahia, a utilização do seu grande patrimônio cultural, artístico, folclórico, em termos de coisa organizada; o interesse pela vida baiana foi tal, entretanto, que recebeu o Governo, nestes quatro anos, a visita de figuras as mais expressivas dos meios políticos, financeiros e culturais do País, bem como estrangeiros ilustres, entre eles o Príncipe Phillipe da Inglaterra, o Rei Leopoldo da Bélgica e vinte e seis embaixadores. Tive a honra durante o meu governo de ver realizados na Bahia os "Colóquios Luso-Brasileiros" e a reunião do "Conselho Mun- dial de Tensões", conclaves que possibilitaram a expressões culturais e políticas de outros continentes o conhecimento de nossa terra e da sensibilidade da nossa gente. ${ }^{9}$

Num movimento mesmo que implica uma espécie de "descoberta do povo" por trás dos patrimônios culturais, a sentença a respeito da "sensibilidade da nossa gente" parece tornar cúmplices as expressões populares do ideário acerca dos "valores baianos", ideário que, por sua vez, seria o núcleo das "tradições da cultura da Bahia". E ela já se situa como o bem raro elementar e decisivo em torno do qual deveria orbitar o sistema turístico local-regional. Arriscaríamos propor que, àquela altura, a figura de uma auto-imagem coletiva da Bahia já estava posta em suas linhas gerais, e os enunciados dispostos no discurso governamental o atualizam, ao tempo que persevera a autoridade do Estado em atuar sobre tal objeto. A figura do povo (com sua sensibilidade lúdico-artística e religiosa) está escudada no a priori da tradição, como forma de narrativa e compreensão social, delimitando uma moldura ideológica de integração de componentes materiais e simbólicos e prescrevendo os critérios de inserção de cada uma das partes à totalidade, assim definida pelo imperativo do "berço da nação".

Contudo se faz necessário observar a maneira como a figura do ente povo se insere como conteúdo dessa moldura ideológica, a qual se tornará elemento decisivo bem potencializado nos projetos de modernização turística na Bahia. Uma vez mais retornamos à década de 1930, já que, em tal período, também a ressemantização da idéia de tradição parece ter por anverso o acento maior no tema do povo da Bahia, deslocando os aspectos arquitetônicos para a posição de cenário das manifestações desse ente mítico étnico-político. ${ }^{10}$ Eviden-

Fonte: Fala do governador Juracy Magalhães, 20/11/1963, p. 24-25.

10 Tomamos aqui de empréstimo a idéia de Cassirer (2003) de perscrutar as conexões entre mito e estado-nação. Em particular nos interessa reter a concepção de "povo" como um ente etnico-político constituído por relatos artísticos e intelectuais, mas tendo a capacidade de superar, na sua própria natureza de fábula, as contradicões inerentes às heterogeneidades de várias ordens existentes nos conjuntos demográficos sobre qual se ergue como fator de unidade. 
temente, sabemos estarem os tantos planos da experiência societal e das instituições como os objetos entretidos, ou tecidos por feixes sociodiscursivos. No entanto, o alvo do interesse analítico deve agora se deslocar do domínio dos enunciados propagados pelo ordenamento estatal para as mediações discursivas exercidas por determinados círculos de sociabilidades intelectuais, na significação de algumas práticas e símbolos como suportes da narrativa a respeito de uma Bahia compromissada com a exemplaridade do passado. Entendemos as mediações à maneira de correias de transmissão de saberes em redes, com interdependências sociofuncionais, nas quais as agências intermediárias, com seus dispositivos de expressão e comunicação, interferem tanto na compreensão quanto na composição dos termos mediados, ao os dotarem de sentidos de reciprocidades. Supomos que esteja, nas mediações exercidas por certas facções intelectuais situadas em Salvador, na primeira metade do século XX, a possibilidade de apreender os movimentos pelos quais enunciações provenientes de áreas diferentes estavam continuamente veiculando insumos de sentido, e a recursividade dessas interações teve por conseqüência não programada um ajuste semântico e sintático, justamente tornando equivalentes tradição e povo baiano. Propicia-se, assim, um objeto discursivo posteriormente transportado para o interior dos enunciados do poder público local e regional. Portanto, ao longo da argumentação, reteremos o tema da ideologia com referência à apreensão das performances discursivas, e essas sob o ponto de vista de práticas capacitadas a significar outras práticas. Entendemos que a opção permite observar como determinados saberes adquirem o status de falas autorizadas a delinear os lugares da tradição e, ainda, classificar e qualificar os seus ocupantes. Logo, de acordo com a perspectiva foucaultina, o saber se define como um espaço no qual está posicionado o sujeito para enunciar os objetos (Foucault, 2000, p. 217). Entendemos que os discursos da e sobre a tradição delimitam também um campo de coordenação e de subordinação dos enunciados, em que os conceitos aparecem, se definem, se aplicam e se transformam. Entretanto, a nosso ver, dizer que o sujeito está estruturado não corresponde à eliminação da intencionalidade da agência humana nas tramas interacionais e institucionais, tampouco equivale a desprezar os efeitos estruturantes da intenção sobre os desdobramentos dos sistemas sociais.

Nesse sentido, embora a proposta não seja aqui a de observar uma "invenção de tradição" (Hobsbawn, 1997, p. 9-23), ou seja, a construção intencionada de um relato pelo qual se define um arbitrário início de uma entidade sociopolítica reverenciada nos protocolos de rituais nacionais, interessa-nos ver a maneira como, nos trânsitos discursivos interinstitucionais, a ênfase na idéia de tradição demarca posições socioculturais. E ainda como, para algumas agências humanas e grupos, obter o consentimento e o reconhecimento como um dos pontos de visibilização da Bahia como tradição se reverberou em uma estratégia de extração e acumulação de capital social raro e fonte de distinção, capacitando-os, com isso, a sair do ostracismo, ainda que retroalimentando hierarquias vigentes. Desse ângulo, no trajeto da pesquisa, observamos que, já evocada desde o final do século XIX, apenas na década de 1920 se deu o advento da tradição como problema nítido entre círculos intelectuais situados em Salvador, principalmente na Academia de Letras e no Instituto Histórico Geográfico da Bahia. Naquele momento, a sociabilidade abrigada nesse último órgão se devotara fortemente à disjunção entre tradicionalidade e civilização. Assim, assinado J.G. Lemos Brito, vem a público, na revista do Instituto, o artigo intitulado O Valor das Tradições. Ao longo do texto, o autor parte da percepção do descrédito da tradição. $\mathrm{Ou}$ seja, a seu ver, feneceram os partidos de idéias e costumes diretamente vinculados aos valores religiosos de uma igreja católica interna ao Império brasileiro, diante do "ódio ao passado" decretado pelos advogados republicanos do "progresso humano". ${ }^{11}$ Sua revolta é concentrada naqueles que

${ }^{11}$ A reafirmação dos laços com o recente passado imperial é recorrente entre intelectuais baianos da época. Provavelmente, o mais refinado esforço nesse sentido seja o livro Salóes e Damas do Segundo Reinado, de Wanderley 
detratavam a memória de um passado construído na congregação de esforços que viabilizaram a cidade. Por isso, move-se de modo hostil aos defensores da derrubada do monumento ao "caboclo", na Praça do Campo Grande, para substituí-lo por outro, agora em reverência a José Bonifácio de Andrade. Mesmo rendendo homenagem ao nome maior da independência nacional, o autor reafirma a sua lealdade à singularidade da luta e da conquista baiana pela autonomia frente à metrópole lusitana. O "caboclo" é apresentado, no artigo, como símbolo de uma pátria que "despertou da puberdade, e, sentido-se varonilizada, deu o braço às armas, até expurgar o estrangeiro (...)" (Britto, 1919, p. 304). O exulto do autor para o Estado preservar as tradições se justificaria pelo ideário de concórdia, de harmonia nela guardado. Enfim, o culto ao caboclo condensaria o espírito cívico de um povo cujo canto é o da "felicidade humana", já que sua terra não conheceria...

... as revoltas das multidões, os ódios de classes, as lutas de partidos, as recriminações (....), porque aqui é a terra do trabalho, da ordem e da lei. Tudo, neste ambiente, doirado pelas radiações do Sol, respira o hálito divino da justiça. $\mathrm{O}$ amor guia conduz as almas. A transparência do ambiente que nos cerca é menos luminoso do que a do nosso ideal. (1919, p. 305).

Hospedados no mesmo Instituto Histórico Geográfico, e também solidários no empenho de preservar as tradições, agora já denominadas de "baianas", outros intérpretes, como João da Silva Campos, dispôs-se a coletar crônicas da "Bahia velha", recolhendo narrativas orais e mesmo algumas escritas, as quais nem sempre estariam de acordo com a "verdade histórica" (Campos, 1930, p. 353-357). Embora a princípio atento a diferentes traços da tradicionalidade local, no decorrer desse período, o foco cada vez mais se dirige ao que o romancista Xavier Marques ${ }^{12}$ batizou de "tradições

Pinho. Ativista na defesa das "tradições", o autor se volta aos "elegantes" ambientes de reunião "alegre e frívola” das classes abastadas em busca de uma polidez emanada da presença feminina; um refinamento que teria se diluído nos tempos de modernidade (Pinho, 2004, p. 9-15).

${ }^{12}$ A crítica literária costuma definir Francisco Xavier Ferreira Marques como pioneiro na "construção de uma religiosas da Bahia” (Marques, 1929). Particularmente, os festejos ao Senhor do Bonfim são destacados. O próprio Xavier Marques deles se ocupou, combinando interesse etnográfico e histórico com a finalidade de mostrar o vigor da comemoração em meio às transformações que sofreu, às disputas entre autoridades eclesiásticas ciosas da ortodoxia religiosa e as heterogêneas massas devotas, mais propensas a fazer transigir mutuamente o sagrado e o profano. Tensões que desvelam dois mundos aparentemente por princípios distantes entre si: o interior sacro da nave da igreja e o alarido do ar livre. Aí, a gente de "todas as castas e matizes, com bateria, bacias, esfregões e vassouras" faria uma lavagem aliando água e álcool, combinando paradoxos de "benditos e chulas, de rezas e gargalhadas, de gestos contrictos e bamboleiros impúdicos" (Marques, 1929, p. 380). Para o autor, a extraordinária opulência humana, com suas expressões da festa, capaz de parar e atrair toda a cidade, estava no fato de manifestar que o "baiano quer entrar no céu, mas com alardo e fanfarra" (1929, p. 381), já que a devoção ao Bonfim expõe o traço próprio ao povo da Bahia, em seus "instintos e sentimentos religiosos", propriedade particular na qual...

Orando e folgando, ele - o povo - nos dá, há um tempo, um espetáculo delicioso e piedoso, talvez paradoxal aos olhos daqueles que só encaram na religião a austeridade das cerimônias e alto objeto do culto, mas certamente um espetáculo humano, ou pelo menos brasileiro, especialmente baiano, em que há lugar para todos os júbilos e exteriores testemunhos de conciliação com a vida, por intermédio do supremo mediado, só não havendo lugar para a hipocrisia. (Marques, 1929, p. 82).

Se o autor se indispõe com a severidade ortodoxa da autoridade eclesiástica, é porque reco-

estética de baianidade na literatura nacional". Teria formulado um repertório fundamental ao desenho de uma Bahia pitoresca, incluindo nela a cultura afro-brasileira no apelo ao exótico-esteriotipado, quando descreve o cotidiano da população negro-mestiça e os rituais aos orixás. Dúbio em sua visão que, a um só tempo, repudia as cores africanas em favor do ideário cortesão propagado desde o Rio de Janeiro, como em Uma Família Baiana. Mas foi o primeiro escritor branco a inserir personagens negros em seus romances, dando-lhes posição de destaque, como em $O$ Feiticeiro. (Jesus, 2007). 
nhece no povo o protagonista da festa de devoção ao santo maior da Bahia. E a imagem de povo que apresenta é aquela de um artista espontâneo, encenador de um espetáculo no qual a profanidade, a barbárie e o sagrado são entrecruzados em nome de uma concepção larga de participação, em favor da tolerância de credos e modos de expressão da fé e de uma peculiar democracia lúdico-religiosa que acolhe cores e matizes humanos distintos. Semelhante ao que Moraes Filho propôs sobre a cultura popular brasileira, à luz da experiência carioca, no final do século XIX ${ }^{13}$ Xavier de Brito exalta a tradição religiosa baiana pelo seu potencial de miscigenação racial, classista e simbólico-cultural. Escudado em Cardoso de Oliveira (2006, p .117-200), quando observa a decisiva participação da elaboração e das interlocuções dos intelectuais na afinidade estabelecida entre ideologia catalã eidentidade catalã, podemos dizer que, em tal intervenção discursivoliterária, são realinhados os termos da idéia de tradição baiana, enfatizando-se sempre mais o componente étnico-cultural, artístico e religioso como inerente à identidade dessa totalidade. ${ }^{14}$ Nesse sentido, a mesma década de 1930 é emblemática do gra-

${ }^{13}$ Literato, memorialista e folclorista baiano, posteriormente radicado no Rio de Janeiro, Alexandre José Moraes Mello Filho se destaca como um dos primeiros intelectuais a não apenas propor, mas também a promover o reconhecimento da cultura brasileira como um portentoso "caldeamento estético", amalgamando uma polifonia de vozes amanhadas pela originária reciprocidade de raças e culturas, tradições e ímpetos, desde agora manifestações do "espírito do povo". De acordo com sua narrativa em Festas e Tradições Populares no Brasil, o grande encontro racial e a miscigenação cultural promoveram o caldeamento colonial de uma nacionalidade "musical e festiva", sendo rememorada e expressa nas artes do povonação. Segundo a versão do intelectual, a Colônia é definida como o palco originário de uma pátria mestiça, onde as sincréticas soluçóes populares dariam o tom de uma originalidade brasileira.

${ }^{14}$ A partir dessa década, sucedem-se obras literárias que focalizam a cidade de Salvador pelo pitoresco das suas imagens coloniais e afro-brasileiras. Se as canções de Dorival Caymi e os livros de Jorge Amado têm ascendência na formação de um imaginário nacional e internacional sobre uma sedutora Salvador, mística e preguiçosa, de cores e sabores negro-mulatos, Bahia: imagens da terra e do povo, de Odorico Tavares, abre uma vertente, ao retratar a capital baiana, correlacionando festas populares e religiosas em um sítio onde o mar intervém nos diferentes planos da vida urbana. Retrato que refletiria, segundo o relato do autor na nota à terceira edição do livro, a "emoção nem sempre contida, pelo que me mostra, em permanente descobrimento, a face múltipla desta cidade conquistada com ternura e amor." Nessa terceira edição, as imagens literárias são vertidas nas figurações do artista plástico Caribé. dual deslocamento do estatuto do tradicional na Bahia. Ou seja, o conteúdo fornecido pelas práticas e simbologias populares, aos poucos, parece ocupar espaços antes reservados aos signos das elites de formação ibero-católica.

Sem dúvida, o aspecto sociocultural da religiosidade é bem ilustrativo a respeito. Voltandonos aos jornais da época, diante do avanço da "civilização", isto é, do ritmo de mudança do cenário urbano, que estaria mais afinado com a sociedade industrial capitalista, não é incomum encontrar vozes que se levantam contra o declínio do que era reconhecido como as verdadeiras tradições baianas, a saber, os ternos da Lapinha, durante a comemoração ao Dia de Reis. Enraizadas no passado colonial, aquelas manifestações seriam vestígios da herança luso-católica. Mas, como que fazendo coro com a percepção de Xavier Brito, também, nesse momento, é suscitada a atenção aos costumes e às práticas profanas e religiosas das massas de descendentes negro-africanos na cidade. Em especial, o culto dos orixás (candomblé) angaria adeptos e simpatizantes entre membros das classes médias, sobretudo dos intelectuais (em geral, cientistas sociais, historiadores e jornalistas). Exatamente pela mediação desses, aos poucos, o universo lúdico e religioso negro-mestiço na cidade adquire espaço de divulgação nos jornais, já não restrito ao tratamento policial. Assim, o sepultamento da babalorixá Mãe Aninha (Eugênia Ana dos Santos) do terreiro Ilê Opô Ofonjá é destacado na primeira página de O Imparcial. No texto, o jornalista mantém o raciocínio dual, distinguindo a cidade que se "moderniza" no compasso da "civilização" do seu povo daquele "pedaço da África” nela "latente nas camadas da cobertura racial", pleno de expressões do "velho Congo", à espera da "primeira oportunidade para mostrar-se em toda sua pujança". E essa se deu por ocasião da reverência inter-classe (e inter-racial) ao prestígio e à autoridade da liderança religiosa morta: "Foi o caso, ontem, do enterro de Aninha, a famosa 'mãe de santo`, tão conhecida de todos e que tantos anos batia candomblé na cidade. Foi um espetáculo fúnebre excepcional, não só pelo pitoresco ritual, mas pela 
multidão que reuniu presentes pessoas de todas as camadas sociais." 15

Contudo, o aparente espanto, a princípio gerado pelo vigor dos traços africanos na capital da Bahia, era paralelo à aproximação de intelectuais inscritos no espectro ideológico mais à esquerda a certas lideranças do candomblé. A própria babalorixa de Mãe Aninha é bem representativa do acerto em curso. Um dos nomes mais prestigiados da história das lideranças do Candomblé baiano, nos anos de 1930, ao lado de outro importante sacerdote, Eliseu Martiniano do Bomfim, ela encabeçou alianças com membros das oligarquias e dos setores médios; negociações cujos efeitos se fizeram fundamentais para a relativa tolerância da polícia às atividades religiosas afro-brasileiras, naquele momento. Ao mesmo tempo, ambos os sacerdotes tiveram destacada participação no II Congresso Afro-Brasileiro, realizado em Salvador, em 1937. Iniciativa e organização do folclorista Édison Carneiro e do psiquiatra e antropólogo Arthur Ramos (Lima, 1987, p. 39-73), o evento lança as bases para o desenrolar dos estudos afrobaianos e, igualmente, para a fundação da União das Seitas Afro-Brasileiras da Bahia, primeira federação do gênero no Brasil. Por outro lado, o congresso deu visibilidade à imagem lúdico-pitoresca de personagens populares do cotidiano soteropolitano, que estavam sendo incluídos entre os arcanos da "cultura do povo" e da tradição baiana, à maneira dos capoeiristas e das baianas vendedoras de acarajé. Assim, na passagem à década de 1940, os relatos jornalísticos que informavam a opinião pública atenuam o que se considerava a natureza “arcaica” do candomblé e de outros aspectos do patrimônio cultural negro-mestiço, agora cada vez mais ressaltado nos enunciados e imagens de Salvador, ao lado do Mercado Modelo e do Elevador Lacerda (Farias, 2001, p. 49-50).

${ }^{15}$ Fonte: O Imparcial, 04/01/1938.

\section{UM CENÁRIO ÉTNICO-BAIANO PARA A MODERNIZAÇÃO TURÍSTICA}

Mantendo o mesmo eixo teórico-analítico fundado na premissa dos envolvimentos de saberes e poderes para a elaboração de aparatos discursivos que definem objetos de intervenção institucional tomada como legítima, e ainda considerando a mediação discursiva exercida pelos quadros artísticos e intelectuais, nesta última seção nos interessa argumentar a respeito de como o encontro entre ordenamento estatal e as memórias ressignificadas dos sistemas de práticas lúdico-artísticas e religiosas negro-mestiças de Salvador permitiu o engajamento entre modernização turística e tradição na Bahia, aninhado no espaço do Centro Histórico, o qual foi diferenciado na ecologia urbana como cenário étnico-turístico reservado à diversão, ao lazer e ao consumo cultural. Para isso, interessa pontuar a importância da ingerência da tradição como uma categoria a priori de entendimento, mobilizada no domínio discursivo do poder estatal, mas também da iniciativa privada empresarial, em particular a partir dos anos de 1950.

Em se tratando do período focado, um primeiro aspecto a ser ressaltado é o quanto o domínio cultural passa a ter uma centralidade, na medida em que a universidade se antecipa como um espaço de reelaboração de significados e de linguagens. Vale lembrar que, somente na década de 1930, com a criação da Universidade de São Paulo e da Universidade do Distrito Federal, o perfil acadêmico-universitário ganhará nitidez no Brasil, com a centralidade ocupada pelas faculdades (ou institutos) de filosofia, na congregação das partes em função do todo, dentro de uma sistemática disposta de acordo com os critérios administrativos, pedagógicos e científicos de hierarquização do conhecimento, acoplando equipamentos para os cursos nas ciências físicas, naturais e humanas. Para além dessa dimensão propriamente pedagógicoacadêmica, os aportes renovadores nas artes e na literatura vivificados, também, nos anos de 1920, se tornaram fundamentos de uma "tradição nacional”. Para compreender tal tendência, cabe ressal- 
tar o quanto a criação ou reestruturação das universidades brasileiras estiveram imersas em um processo de state building - o qual poderíamos traduzir de modo impreciso, como formação do Estado. Desse modo, a universidade surge, no Brasil, como dimensão modernizadora de uma razão de Estado nacionalista. De acordo com Simon Schwrtzman (1984), o resultado foi uma autonomia refluída, para caber nos ditames exacerbados de uma regulamentação que respondia ao empenho governamental em estabelecer a uniformidade institucional, lançando mão, para isso, de um controle rígido, mesmo autoritário.

No que toca aos desdobramentos da implantação desse equipamento de ensino superior no contexto baiano, em meados da década de 1940, embora sem um plano estratégico, mas reunindo as antigas faculdades de direito e medicina já existentes, a vigência do modelo institucional centralizado permitiu aproximar a instituição, nos anos de 1960, do projeto de desenvolvimento urbano-industrial. Esse, ao diagnosticar o "atraso" do estado da Bahia frente aos do Centro-Sul do país, em especial ao êxito da industrialização paulista, tinha por meta intensificar a integração e unificação sociodemográfica. Engajada pelo mesmo objetivo à Comissão de Planejamento Econômico do Governo Estadual - composta durante a administração de Antônio Balbino, na década de 1950 -, a direção da Universidade da Bahia se dispõe tanto a mapear a situação socioeconômica de um estado encerrado em uma estagnada economia agrícola, quanto a implementar um amplo programa de educação e de formação de quadros técnico-profissionais para a montagem de um parque industrial nativo, valendo-se, sobretudo, dos vastos recursos minerais existentes, com destaque para a prospecção de petróleo (Aragão, 1999, p. 42-45). Oreitor na época, o professor Edgar Santos, abraça o projeto nacional-desenvolvimentista, mas prioriza a formação de elites meritocráticas (ibidem p. 46-48).

Se os impasses que marcam a aposta no desenvolvimento industrial reverberam no desempenho aquém da Universidade da Bahia em formar quadros técnico-profissionais para o setor secundário da economia, a mesma instituição já vi- nha obtendo destaque na área das artes - música, artes cênicas e dança. Assim, a despeito das orientações polítco-ideológicas e do seu propósito elitista, o reitor Edgar Santos selou compromisso com o princípio de renovação artístico cultural e, com isso, deixou aberta a fresta para a inserção de grupos modernistas inscritos no espectro da esquerda, em grande medida locados nas fileiras do Partido Comunista. Desse modo, a plataforma do ideário nacional-popular favoreceu uma pauta de pesquisas cujo objeto era o conhecimento dos modos de vida e de expressão dos segmentos subalternos da Bahia, com relevância posta na população negro-mestiça (Teixeira, 1999, p. 73-88). Para o que nos interessa argumentar, outro ramo do saber adquire certo destaque, o das humanidades, justamente no caudal da institucionalização dos estudos afro-americanos, especialmente no compasso das contribuições de Melville Herskovits, Roger Bastide, Arthur Ramos e Édson Carneiro (Yelvington, 2007), mas nos rastros do mesmo imperativo desenvolvimentista que vicejou, seja no convênio entre a Secretaria da Educação da Bahia e a Universidade da Columbia, em 1949, seja no projeto Unesco, no início dos anos cinquenta (Azevedo, 1984, p. 72-77). ${ }^{16}$ As pesquisas etnográficas e antropológicas voltadas para a cultura africana e os estudos de comunidades negro-mestiças são estimuladas.

Um marco a respeito é a criação do Centro de Estudos Afro-Orientais (CEAO), sob inspiração intelectual do filólogo, literato e livre-pensador português Agostinho Silva. Exilado em virtude da ditadura salazarista, ele porta um itinerário de formação nas humanidades realizada em Paris, tendo por interlocutores representantes de um pensamento romântico crítico da modernidade burguesa e disposto a resgatar a vitalidade humana denegada pela epistemologia industrial-

${ }^{16} \mathrm{O}$ diálogo entre os dois últimos intelectuais deixa entrever tanto a maneira como se definiu o universo da população negro-mestiça como objeto de interesse intelectual no Brasil, especialmente na Bahia, deslocando-se da questão médico-jurídica ao sociosimbólico, quanto sinaliza os caminhos institucionais que foram percorridos para que os estudos sobre o universo religioso afrobrasileiro adquirissem legitimidade acadêmica no país (Oliveira; Lima, 1987, p. 11-12). 
produtivista. ${ }^{17}$ Ocupado exatamente com o "devir histórico-civilizacional da humanidade e do mundo”, Silva sustentava a bandeira messiânica contida no ideário do "quinto império lusitano" (Silva, 2002a, p. 249-259), de uma “civilização luso-tupi”, alternativa àquela efetivada pelos povos anglosaxões, ao reconhecer naquela a ênfase na cultura em detrimento da centralidade gozada pelo dinheiro no capitalismo (Borges, 2002, p. 14-17). Informado por tal ideário, aceitou o convite do reitor Edgar Santos para liderar a implantação do CEAO. O projeto se inseria no escopo mais amplo das estratégias do governo brasileiro no sistema internacional, naquele momento da geopolítica mundial bi-polarizada entre Estados Unidos e União Soviética. Seguiam-se as orientações diplomáticas predominantes de opção pelo terceiro-mundismo nos governos Juscelino Kubitschek, João Goulart e Jânio Quadros e, ainda, da proposição da Unesco de viabilizar maior intercâmbio cultural entre Ocidente e Oriente. O liame estabelecido abrangeu as viagens de estudos linguísticos, históricos e antropológicos de pesquisadores brasileiros à África e à Ásia, a montagem de departamentos universitários e centros de pesquisa em paises como Senegal, Bulgária, Ceilão, Índia e Japão (Silva, 2002b, p. 37-38).

O quadro de pesquisadores, composto por linguistas, antropólogos, historiadores e mesmo do teatrólogo Nelson de Araújo, orbitava em torno da figura de Agostinho Silva e seu claro propósito de fomentar, na cultura brasileira, a possibilidade de

17 Propondo um inusitado encontro entre Durkheim e Nietzsche, o College de Sociologie consistiu numa corrente lietrário-filosófica que acolheu nomes como o de Roger Callois e George Bataille, em favor de um retorno às forças recalcadas pelo projeto racional-epistemológico do Ocidente. Ilustrativa, na sua leitura original das condições socioculturais do amplo conjunto da humanidade contida no livro A Parte Maldita, Baitalle distingue entre "sociedades de consumo" e "sociedades de empreendimento". A classificação obedece ao parâmetro central oferecido no livro, a saber, a questão do dispêndio. No texto, é perseguido o entendimento de como as diferentes conformações étnico-societais lidaram com a questão posta na oposição entre a aventura e a estabilidade; envolvendo a última está a preocupação com os excedentes. Enfim, na descrição do autor, a humanidade teria se confrontado com o dilema de estar ou na inconstância criativa do ócio, ou na segurança disciplinadora do negócio, na busca tenaz em satisfazer determinačões, necessidades. Mesmo implícita, a referência de Bataille é ao seu mundo de origem, o Ocidente e sua obcecação é por produzir, crescer, ou simplesmente, progredir (1975, p. 82-83) elaborar um modelo civilizatório próprio, não restrito ao olhar litorâneo resignado em mimetizar o objeto de sua saudade - a Europa - e (ou) a fazer a cópia do modo de vida da América do Norte. Exultava uma educação apropriada a potencializar o artista e o cientista existentes em qualquer indivíduo (Silva, 2002c, p. 245-246). À semelhança do modernismo brasileiro, abria-se caminho para estudos que privilegiam o autóctone e, como no mesmo modernismo, deu-se total relevo às práticas e aos símbolos do que era reconhecido como cultura popular. Aspirando essa atmosfera, as componentes linguísticas, religiosas e folclórico-culturais da população negro-mestiça de Salvador e adjacências são efetivadas no status de objeto de conhecimento científico.

Primeiro nome incluído no elenco desses pesquisadores, o antropólogo e professor do curso de Ciências Sociais da UFBA, Vivaldo da Costa Lima, obteve destaque pelos estudos sobre as "famílias de santo" inter-geracionalmente geradas e que habitavam nos terreiros de candomblé (Lima, 2003).$^{18}$ Durante uma entrevista, concedida ao autor deste artigo e a seu - na época - assistente de pesquisa, que visava a reconstruir a memória da formação dessa elite intelectual, perguntado se foram motivações político-ideológicas que o introduziram no seio do candomblé, Costa Lima traduz o sentimento que o levou àquela sociabilidade religiosa:

Não, não creio que houvesse, devia ter havido apenas uma coisa existencial [...]. O Jornal A Tarde me fez essa pergunta que você me fez agora. [...] Eu respondo que não fui eu que descobri o Candomblé, foi o Candomblé que me descobriu, foi através do Candomblé que eu voltei a ter interesses, comecei a ter interesses sistemáticos pela

${ }^{18}$ Vivaldo da Costa Lima se constituiu em espécie de ponte intelectual entre o Projeto Unesco e a experiência do CEAO. Odontólogo de formação, ele iniciou seu percurso acadêmico e de pesquisador em antropologia ao participar do Laboratório de Fonética da UFBa, a cargo do professor e linguísta Nelson Rossi, que se dedicava ao estudo dos falares baianos, na época. No laboratório, ele conheceu Agostinho Silva, em 1960. Sua ida para o CEAO está relacionada a um estudo pioneiro sobre a festa de xangô no terreiro de candomblé do Ilê Opô Afonjá apresentado no IV Colóquio Internacional de Estudos Luso-Brasileiros, em 1959, promovido conjuntamente pela UFBa e a Unesco. Nesse trabalho, o autor descreve o ritual inserindo-o no "vasto complexo religioso"- que se aninharia nas "casas de santo" (Costa Lima,1959). 
religiosidade e essas coisas, enfim, o Candomblé que me descobriu mais do que eu a ele. Porque eu não fui estudar o Candomblé para descrever sobre o Candomblé; quando eu fui pra Universidade, eu já era um frequentador antigo do Candomblé, e foi porque eu era um frequentador do Candomblé que eu pude organizar essas pesquisas com uma certa facilidade, um certo trânsito, eu era amigo de todas as grandes casas da Bahia, não é? Eu era, nessas casas pioneiras da minha pesquisa, antes das centenas que foram fichadas depois [...], eu era amigo desses pais e mães-desanto todos, que só tem um vivo hoje que é Olga do Alaketu. Desses primeiros, todos os outros eu vi morrer, assisti morrerem durante a vigência; estão sendo substituídos durante a vivência [...]. ${ }^{19}$

Se os laços afetivos antecederam os interesses científico-intelectuais, institucionais e acadêmicos na inserção do antropólogo no mundo do candomblé, sua ida aos terreiros é parte - vimos de uma já longa sinergia entre acadêmicos e lideranças religiosas afro-baianas. Essa troca foi decisiva para legitimar um campo temático científico no qual se abriga a identidade de um novo círculo intelectual que, ao tomá-lo por objeto de conhecimento, conferiu pontos preciosos ao reconhecimento da identidade desse universo sócio-humano e cultural como aspecto da vida e da tradição baiana, no momento em que o discurso intelectual fornece categorias de pensamentos incorporadas à reflexividade nativa, a saber, tradição e nação (Lima, 1976, p. 65-90). Tais categorias são inerentes ao esquema analítico e interpretativo que apreende o traço de continuidade civilizatória da memória iorubá-nagô, matriz cultural que teria sido reposta e atualizada pelas lideranças religiosas do candomblé à frente das suas respectivas casas de santo. Sendo também portadora de uma tradicionalidade, a identidade desse último grupo contorna, assim, a mácula da discriminaçãoétnico-racial e assegura uma posição de prestígio. Incorporada tal categoria no delineamento da sua honorabilidade, a linhagem dos babalorixas se insere diferenciadamente no mercado religioso, no qual oferece um serviço que atende a uma clientela inter-classes. Ao mesmo tempo, a aura de nobreza fundada em uma tradição estendida desde a África se traduz em um su-

${ }^{19}$ Entrevista concedida por Vivaldo da Costa Lima a Edson Farias e Fernando Rodrigues, em 10 e 15 de fevereiro de 2004 . porte de identificação para uma ampla população recém-saída da escravidão, despreparada para enfrentar a concorrência do mercado de trabalho e mal amparada para atuar autonomamente na arena política dos fóruns de representação no Estado. ${ }^{20}$

Mas é verdade também que a reciprocidade de ideários e interesses entre os dois polos encontrou respaldo no cômputo das elites políticas, porque veio a subsidiar, naquele momento, a ideologia acerca da singularidade do senso de pertencimento a uma mesma memória coletiva sincrética e também àquela sintética identidade baiana, sendo ambas elementares à imagem de um ente étnicopolítico peculiar no seu modo de ser e agir, ao mesmo tempo moderno e tradicional, cosmopolita mas comunitário (Capone, 2004, p. 217-326; Santos, 2005, p. 56). Já tecida desde os anos de 1930, por outros intermediários culturais (literatos, jornalistas e historiadores), essa imagem logo terá repercussões no encaminhamento dado à modernização turística em Salvador. Com isso, a aliança tácita forjada repercute em planos mais amplos da cidade, desde a década de 1960. Sugere-se, então, que a trama das interdependências sociofuncionais tornava relacionados grupos, a princípio, posicionados em pontos distantes do espaço estratificado e, logo, da hierarquia social. Ou seja, as diferentes estratégias de participação nesse espaço, adotadas pelos respectivos agentes (intelectuais, elites políticas e lideranças lúdico-artísticas e religiosas), compatibilizavam-se pelo a priori da tradição baiana. Parece que ela os tornava, de algum modo, próximos, na proporção em que se ritualizava nos espaços de um congraçamento popular ecumênico, viabilizado nas performances lúdicas e religiosas dos anônimos comandados pelas lideranças musicais e do candomblé: na devoção das festas de largo, a exemplo ao Senhor do Bonfim; nos cultos aos orixás e, mais recentemente, nas multidões puxadas pelos trio-elétricos mo-

\footnotetext{
${ }^{20}$ Embora saibamos que se trata de um tema bem mais complexo, que envolve outros planos analíticos, abarcálos escapa aos objetivos deste artigo. Dois trabalhos recentemente editados oferecem um quadro amplo e aprofundado da formação e desenvolvimento do can-
} domblé em Salvador (Parés, 2006; Silveira, 2006). 
vidos à base da percussão musical. ${ }^{21}$

No escopo desse feixe de interdependências, o convite do então prefeito Antônio Carlos Magalhães para Costa Lima dirigir a comissão encarregada de um levantamento socioeconômico, com a finalidade de elaborar um projeto de preservação do Centro Histórico de Salvador (Pelourinho, 1967), notadamente da área do Pelourinho, tanto evidencia outro patamar na constelação cultura e estado na Bahia quanto notabiliza o percurso que o torna possível. O relato do próprio antropólogo deixa entrever um e outro aspecto:

Na época em que ele - Antônio Carlos Magalhães - ainda era um jovem prefeito interessado em criar algo de novo na administração pública e tal. Nessa época ele teve a idéia de criar um projeto de renovação do centro histórico, não é?

[...] Eu estava na Universidade, era professor da Universidade, então aceitei [...]. Eu já conhecia Antônio Carlos da infância nossa comum, ali no Campo da Pólvora, fomos vizinhos [...]. Ele é mais novo do que eu dois anos. Foi por isto que eu fui convidado pelo Diretor do Departamento de Turismo naquela época da prefeitura, o jornalista Flávio Costa, para coordenar essa pesquisa. Primeiro fazia um levantamento, não havia esse.. Foi a partir desse levantamento que eu fiz, inclusive, com ajuda de Júlio Braga, que foi meu assessor de pesquisa, entendeu?

O decorrer do relato de Vivaldo da Costa Lima expõe seu desacordo com o destino turístico dado à reforma do Centro Histórico, iniciada em 1971 e prolongada em diversas etapas; resultado que teria se distanciado da concepção original de ocupação daquele espaço, quando esteve à frente do Instituto do Patrimônio Histórico Artístico Cultura da Bahia:

O Pelourinho para mim era apenas uma parte histórica da cidade, não tinha interesse teóricometodológico, tinha interesse por gente, porque eu sou um antropólogo de gente, não sou antropólogo de arqueologia [...] Sempre me interessei muito pelo Pelourinho, a prostituição, a droga, os veados, tudo aquilo que havia institucionalizado,

${ }^{21}$ Em outra oportunidade, em razão de tematizar a correlacão entre música popular e festa carnavalesca em Salvador, mas sob o mesmo prisma teórico-analítico, focamo as teias dessas interdependências compostas pelas estratégias dos agentes e grupos lúdico-artísticos populares baianos e o mercado de bens simbólicos (Farias, 2001, p. 46-82). Também do eixo processual de longa duração histórica e configuracional, Rodrigues (2006) realiza uma abordagem da convergência entre religiosidade afro-baiana e música popular percussiva em Salvador. a veadagem da área, isso sempre me interessou muito. [...] Quando ele me convidou, eu fiz um projeto, esse projeto foi se desenvolvendo de uma maneira utópica, visando que se conservasse a população tanto quanto possível, que se restaurasse para o povo, naturalmente não para a marginália, para os marginais, nem para... Mas aquilo que o Agostinho da Silva chamava dos despojados, os necessitados. Nós conseguimos em parte isso [...]. Mas, aí veio a loucura política, de apoio político, e começaram a distribuir os espaços por pessoas incompetentes para ocupá-los, aí o mundo de lojinhas, de restaurantezinhos sem uma certa formação profissional adequada e tal. E a música, a música axé! Tudo aquilo causou aquela invasão, tudo isso, fizeram do Pelourinho então um bairro turístico, que não era essa a nossa intencão inicial. Era um bairro em que houvesse vida, vida do povo, não é? Inclusive música, inclusive shows, e não mais uma predominância, não é? Mas isso é outra coisa, eu falarei disso melhor, de uma maneira mais crítica, depois.

Por escaparem ao raio de alcance dos agentes e do quadro de valores por eles esposados, as vicissitudes de um processo sócio-histórico podem lhes parecer como paradoxais, até incompatíveis com as suas intenções. Por certo, a posição circunstanciada do agente o teria impedido de antecipar os rumos da obra, na medida em que não poderia prever e nem mesmo controlar os efeitos das interdependências sociofuncionais que se davam no movimento mesmo em que estavam incluídas as suas tomadas de posição. As intervenções de intelectuais como de Vivaldo da Costa Lima se fizeram cruciais para a efetivação de parcelas lúdicoreligiosas do universo negro-mestiço no domínio da tradição da Bahia. Mas igualmente se observa, retrospectivamente, o paulatino concatenar da gama de práticas e símbolos inseridos nessa tradição com a sistemática turística. Então, se não foi gratuito o fato de o convite ao antropólogo, para realizar o mapeamento socioeconômico do Centro Histórico, ter partido do então diretor da Superintendência de Turismo de Salvador - SUTURSA -, é por ter selado o ajuste que plasma o termo comum à dinâmica histórica da modernização turística na experiência baiana.

O acabamento do argumento requer a perspectiva da dinâmica histórica do processo aqui estudado, sempre tomando por corpus os jornais em circulação em Salvador. Neles, encontramos, a partir da segunda metade da mesma década de 
1930, a regular presença de matérias que noticiam o "dilúvio de turistas" desembarcados no porto, provenientes da Europa e dos países mais ao Sul da América do Sul. Denominando Salvador de a "cidade do turismo", uma das reportagens se refere à descoberta da capital da Bahia como um destino até então mantido secundário, apesar de possuir "valores artísticos, históricos e naturais”. A mudança de atitude por parte das companhias internacionais seria efeito da atuação conjunta da Cia de Viagens Conde, do Rotary Club e do Touring Club, ${ }^{22}$ contando, para isso, com os serviços do hotel-cassino Palace. Alguns meses depois, o mesmo jornal noticiaria a instalação da Diretoria de Cultura e Divulgação, que absorvia, em seu esquema organizacional, a Sessão de Turismo, oriunda da antiga e pioneira Diretoria de Arquivo e Divulgação, logo inserindo a visibilidade turística entre as suas funções de disciplinar a propaganda no e do Estado. ${ }^{23}$

Não se trata aqui de fazer a reconstrução do itinerário da montagem institucional do turismo, em Salvador, até porque o estudo de Lúcia Aquino Queiroz já oferece um quadro bem completo a esse respeito (Queiroz, 2002). O mais importante é anotar que, se a instalação da Sessão de Arquivo e Divulgação foi o ponto inicial da escalada de normatização, com o ordenamento público das atividades turísticas na Bahia, as situações noticiadas permitem atentar para a existência e o alinhamento de forças internas à sociedade civil, interessadas nas atividades afins ao comércio de viagens, diversão e lazer. Foi a articulação composta por tais facções da iniciativa privada e dos setores inseridos no Estado que viabilizou, no final da década de 1960, a reforma do Centro Histórico, e ela se fez o marco e o símbolo da alteração qualitativa na modernização turística em Salvador. A eleição desse sítio se deu pela ingerência dos porta-vozes dos interesses e ideários identificados com o turismo, como opção de desenvolvimento local e regional. É ilustrativa a interpelação de Albano Frederico Marinho de Oliveira, durante a década de 1950.

\footnotetext{
${ }^{22}$ Fonte: O Imparcial, 19/09/1938.

${ }^{23}$ Fonte: O Imparcial, 05/11/1938.
}

Entusiasta do desenvolvimento do turismo e estudioso do tema, tendo feito um mapeamento das potencialidades de diferentes cidades brasileiras, esse agente será tanto um estrategista quanto um incentivador da criação de uma Diretoria de Turismo na Bahia. Autor de Roteiro Turístico da Cidade de Salvador, ele propõe a evolução "horizontal" do setor na cidade, com a finalidade de explorar as tantas faces existentes, tornando-as atrativos turísticos. No elenco de atrativos, Marinho de Oliveira destaca necessariamente a combinação entre o sítio tropical, com sua costa marinha, o patrimônio arquitetônico colonial e as manifestações populares lúdico-religiosas, praias extensas, fortes, igrejas, ruas seculares, as diversidades gastronômicas, a cultura popular múltipla e as "festas impregnadas de misticismos” (Oliveira, 1960, p. 34-35).

As percepções e teorizações de Marinho Oliveira irão ressoar no momento em que, na mesma década de cinquenta, o turismo se insere no âmbito do planejamento estatal como parte das estratégias de desenvolvimento elaboradas pela Comissão de Planejamento Econômico, do governo de Antônio Balbino. Nessa ocasião, a Comissão Mista, ocupada em estabelecer um acordo de cooperação entre os Estados Unidos e o Brasil, propõe o auxílio financeiro ao desenvolvimento do turismo brasileiro, gozando de total apoio da Confederação Nacional do Comércio. Entre os seus resultados estará a fundação da EMBRATUR e uma orientação do Plano de Desenvolvimento da Bahia (PLANDEB) para o turismo (1960, p. 53-55). Em grande medida, o plano malogra, mas é também verdade a sua importância para sedimentar uma mentalidade institucional voltada para o turismo no Estado, e ela se realiza a partir de algumas certezas, entre as quais a de que as "tradições populares" da Bahia, como a das baianas vendedoras de acarajé, deveriam constar com total relevância do produto turístico de Salvador (p. 59-60).

O reforço desse quadro de raciocínio se dá à medida que a institucionalização do turismo se estende, sobretudo na segunda metade da década de 1960, período em que, já sob a égide dos gover- 
nos militares, instala-se o Sistema Nacional de Turismo, com o propósito de engajar essa atividade na modernização do país, incentivando a montagem da infra-estrutura de hospedagem e o incremento das rotas rodoviárias e aéreas (Farias, 2006, p. 203-206). Entre os programas postos em execução pela esfera federal de poder, na direção de incrementar o turismo no país, estava aquele de "reforma das cidades históricas". Portanto, a iniciativa do então prefeito Antônio Carlos Magalhães tanto estava informada pela mentalidade de reconhecer, nas tradições da Bahia, decisivo atrativo turístico, quanto se ancorava em uma tendência nacional e internacional, ao se decidir pela reforma do Pelourinho. ${ }^{24}$ A ênfase na recuperação do Pelourinho, de um lado, respondia ao leque de interesses das elites políticas regionais na balança de poder nacional, ao se manter fiel ao alicerce ideológico interno à tradição baiana de evocar a centralidade da Bahia, no tocante à cultura e à formação do Brasil. Algo posteriormente ressaltado pelo diretor da IPAC, durante uma fala comemorativa dos dez anos da instituição responsável pela coordenação da reforma:

Uma metáfora sobremodo repetida nos diz que o Brasil foi batizado na pia da velha Sé de Salvador. Pode-se dizer com a mesma propriedade, que a Igreja do Colégio assistiu sua unção com os óleos da Confirmação! Em resumo, a cultura brasileira recebeu os seus primeiros sacramentos nas terras da Bahia.

As contingências históricas que fizeram de Salvador a primeira capital determinaram que, não somente esta cidade como toda a província funcionassem como polo centrípeto de cultura que deu ao nosso Estado uma posição destacada como detentor de um acervo apreciável de monumentos e bens móveis que merecem, pela sua qualidade, todo esforço possível de preservá-lo. ${ }^{25}$

Mas, de outro, a reforma do Centro Histórico tornava evidente a tendência da balança de poder entre aqueles diversos grupos inseridos nas interdependências sociofuncionais na cidade e no Estado, de enxergar no turismo um horizonte de inserção diferenciada na divisão do trabalho e das

${ }^{24}$ Reforma, aliás, concluída apenas no seu terceiro mandato como governador, em 2004.

${ }^{25}$ Oliveira (1979). funções em escala nacional e planetária, no instante em que ocorriam os primeiros sinais da crescente importância adquirida pela imaterialidade na dinâmica do capitalismo, em especial o consumo de informações, de lazer e de diversão. Os enunciados, que partiam de elites empresariais que apoiaram o projeto de "revitalização" do Pelourinho desde o início, publicizavam a “convicção” de ser o turismo a "principal atividade econômica a que se há de voltar a Cidade de Salvador". ${ }^{26}$ Apoiando-se no diagnóstico dos urbanistas franceses Alain Perkinc e Michel Parent, consultores do projeto de reforma exultavam que a "cidade mais espetacular do mundo" deveria contar com uma infra-estrutura necessária para explorar sua beleza. Belezas estas estendidas do Pelourinho a "todo conjunto de áreas que se contém das Portas do Carmo às Portas de São Bento, que desce à Conceição, atravessa o Comércio, sobe o Taboão e chega ao Pelourinho, se constituindo no Centro Comercial Histórico da cidade”. Desse modo, conclamam a reunião de esforços diversos para fixar a capital baiana no mapa turístico, para isso considerando a matéria-prima constituída pelas lembranças barrocas do apogeu colonial, que deveriam ser preservadas contra os atentados das alterações urbanas - similar ao que, como vimos, diziam os arautos da tradição contra a civilização nos anos trinta. Essas novas formulações dessas elites sobre o turismo apelam para uma modernização capaz de tornar cúmplices o passado das tradições e o presente das inovações:

Urge, pois uma mobilização das forças sociais desta cidade, berço da história e cultura da pátria, no sentido de preservar e realçar as suas origens, não as sacrificando ao argumento da expansão e desenvolvimento urbanístico, antes fazendo coexistir, em harmonia, o passado e o presente, sem negação àquelas origens tão prenhes de grandeza e virtuosidades proclamadas por aí afora, que devem ser cultuadas como monumentos, prodigalizados a nós próprios e quantos nos busquem visitar, o prazer e o lazer, a elevação histórica e cultural. ${ }^{27}$

No seu desfecho, esse enunciado sublinha

\footnotetext{
${ }^{26}$ Revista da Federação do Comércio do Estado da Bahia, 1971.

${ }^{27}$ Idem, ibidem.
} 
o status de patrimônio da Bahia tradicional para, imediatamente, endereçar o mesmo bem históricocultural na direção dos usos do prazer e do lazer, enfim, do entretenimento-turismo. O anúncio está na contramão do princípio que teria informado a participação de nomes como o de Vivaldo da Costa Lima no projeto de reforma do Centro Histórico. Mas, composta também pelo antropólogo e pelas lideranças do candomblé, a aliança entre saberes e poderes - tanto das elites políticas, intelectuais quanto das lideranças lúdicas e religiosas populares em favor da "revitalização" do Pelourinho deu o suporte necessário para o ideário da modernização turística se intensificar na cidade, a partir de um cenário étnico-histórico em que se materializaria a tradição baiana. Com a decepção provocada pelos impasses do setor industrial no Estado, na passagem para a década de 1990 (Druck, 1999), forma-se certo consenso em torno da modernização turística, e ela adquire adeptos e defensores entre os mais diversos grupos. Aquele era o momento em que foi a público o trecho transcrito no início deste texto sobre a adesão dos dotes culturais e artísticos, vinculados aos valores da cultura baiana, às inovações próprias à sociedade contemporânea, entre as quais o lazer e a diversão promovidos pelo sistema institucional turístico. Poderíamos, a essa altura, nos referir a uma intertextualidade, já que uma suposição merecedora de aprofundamento empírico-analítico é a de que a publicidade turística encontra respaldo em um concerto de sistemas de práticas lúdicoartísticas e religiosas dispostas a se tornarem informações aptas a percorrer circuitos cosmopolitas e, desde aí, alvos do olhar turístico, mediante a intencionalidade das agências humanas que as realiza como expressões da Bahia como tradição.

\section{A TÍTULO DE CONCLUSÃO}

Perscrutando a tradição como elemento interno ao repertório da modernidade, neste artigo procuramos verificar sob que condições sócio-históricas tal concepção pode compartilhar do mesmo horizonte interpretativo em que se situa a ideia de inovação. Isso nos levou ao recurso analítico de estudar a sintonia estabelecida entre tradição baiana e sistemática turística em Salvador. Ao se perseguir o trajeto, percebeu-se o modo como a tradição informou os destinos da modernização turística naquele sítio urbano e, por outro lado, deu-se na mesma marcha sua ressignificação como objeto de lazer e diversão. Isso ao se observar como as alianças sociodiscursivas que envolvem elites políticas e intelectuais, ao lado de lideranças lúdico-artísticas e religiosas, estabeleceram posições diferenciadas para os portadores da tradição baiana como um índice de prestígio e mecanismo de consagração.

Ao mesmo tempo, somos levados a concluir que os estudos voltados para processos de ressignificação de memórias e narrativas, em contextos de modernização, por tratarem das confluências entre sistemas de práticas expressivas, técnicas, moralidades e afetos, requerem problematizar as dinâmicas históricas nas quais ocorrem tanto a transmissão dos saberes quanto as modalidades de aprendizado e de reelaboração dos saberes. Isso porque se faz imperativo apreender e compreender melhor, a partir dos mapeamentos empíricos a serem realizados, o modus operandi da incorporação individual dos saberes sociais, processualidade pela qual se capacita a agência humana a modular e modelar os impulsos, dando relevo à maneira como se podem deduzir modos de ser e de agir, linguagens e expressões. Certamente, pesquisas e reflexões a respeito das feições várias da economia simbólica poderão acrescentar às ciências sociais componentes importantes no conhecimento do social como uma dimensão intersticialmente constitutiva da polaridade entre natureza e cultura.

(Recebido para publicação em junho de 2008) (Aceito em outubro de 2008)

\section{REFERÊNCIAS}

ALMEIDA, Paulo Henrique. Serviços estratégicos para o desenvolvimento. Revista da Superitendência de Estudos Econômicos e Sociais da Bahia: serviços estratégicos na Região Metropolitana de Salvador. Salvador: SEI, 2004 (Série estudos e pesquisa, 70). 
AIROLDI, Ãngela; SENN, Lanfranco. Milan, capitale économique. In: PHILIPPE, Jean; LEO, Pierre-Yves BOULIANNE, Louis-M. (Org.) Services et metrópoles: formes urbaines et changement économique. Paris: L’Harmattan, 1998.

ARAGÃO, Rita. Itinerário da universidade no Brasil. In: RUBIM, Antônio Albino Canelas (Org.) A ousadia da criação: universidade e cultura. Salvador: UFBA/Faculdade de Comunicação, 1999.

AZEVEDO, Thales de. As ciências sociais na Bahia. Salvador: Fundação Cultural do Estado da Bahia,1984.

BATAILLE, Georges. A parte maldita. Rio de Janeiro: Imago, 1975.

BAUMAN, Zigmunt. Modernidade líquida. Rio de Janeiro: Jorge Zahar, 2001.

. Identidade. Rio de Janeiro: Jorge Zahar, 2005.

BORGES, Paulo Alexandre Esteves. Introdução: Portugal e o Brasil na senda do pentecostes. Ensaios sobre Cultura e Literatura Portuguesa e Brasileira, Camarate-Pt, Círculo de Leitores, v.1, 2002.

BRITTO, J.G. Lemos.O valor das tradições. Revista do Instituto Geográfico e Histórica da Bahia, Salvador, 1919.

CAMPOS, João da Silva. Tradicões baianas. Revista do Instituto Geográfico e Histórica da Bahia, Salvador, v. 56, 1930.

CAPONE, Stefania. A busca da África no candomblé: tradição e poder no Brasil. Rio de Janeiro: Contra-Capa e Pallas, 2004.

CASSIRER, Ernest. O mito do Estado. São Paulo: Codex, 2003

CASTELLS, Manuel. A era da informação: economia, sociedade e cultura. São Paulo: Paz e Terra, 1999. v. 3.

DANTAS, Paulo Fábio. Tradição, autocracia e carisma. Belo Horizonte: UFMG, 2006.

DRUCK, Maria da Graça. Terceirização: (des)fordizando a fábrica (um estudo do Complexo Petroquímico). Salvador e São: EDUFBA/Boitempo, 1999.

ELIAS, Norbert. Norbert Elias por ele mesmo. Rio de Janeiro: Jorge Zahar, 2001.

FARIAS, Edson. Ócio e negócio: festas populares e entretenimento-turismo no Brasil. 2001. Tese (Doutorado em Ciências Sociais) - IFCH-Unicamp, 2001.

O desfile e a cidade: o carnaval-espetáculo carioca. Rio de Janeiro: E-Papers, 2006.

Tensões em um projeto civilizador baiano (primeira metade do século XX). In: O PROJETO Unesco no Brasil: uma volta crítica 50 anos depois. Salvador: UFBA/ Pallas, 2007.

is FOUCAULT, Michel. A arqueologia do saber. Rio de Janeiro: Forense Universitária, 2000a.

GIDDENS, Anthony. Em defesa da sociologia. São Paulo: Unesp, 2001.

HABERMAS, Jürgen. $O$ discurso filosófico da modernidade. São Paulo: Martins Fontes, 2000.

HAUKNES, Johan. Services in innovation - innovation in services. S14S Final report to the European Commission, DG 12, TSER Programme. Oslo: STEP Group, 1998

HOBSBAWM, Eric. Introdução: a invenção das tradições. In: : RANGER, Terence (Org.) A invenção das tradições. Rio de Janeiro: Paz e Terra, 1997.

JESUS, Liliane Vasconcelos de. Xavier Marques: intérprete da Bahia na virada do século. In: ENCONTRO REGIONAL DA ABRALIC, 23 a 25 de jun., São Paulo: USP, 2007.
LAMOUNIER, Bolívar. O modelo institucional dos anos 30 e a presente crise brasileira. Estudos Avançados, São Paulo, USP, v. 14, n. 6, 1992.

LASH, Scott; URRY, John. Economies of signs and space. London: Sage, 1994

LEED, Eric J. The mind of the traveler: from gilgamesh to global tourism. New York: Basic Books, 1989.

COSTA LIMA, Vivaldo da. Uma festa de Xangô no Opô Afonjá. In: COLOQUIO INTERNACIONAL DE ESTUDOS LUSO-BRASILEIROS,4. Salvador, Universidade da Bahia, Unesco, 1959.

O conceito de 'nação' nos Candomblés da Bahia. $\overline{A f r o-A s i a}$, Salvador, CEAO, n. 12, 1976.

A família de santo nos Candomblés Jejes-Nagôs da Bahia: um estudo de relações intragrupais. Salvador: Corrupio, 2003.

MARQUES, Xavier. Tradições religiosas da Bahia. Revista do Instituto Geográfico e Histórico da Bahia, Salvador, v.55, 1929.

MARSHALL, J, Neill. Services and espace. Key aspects of urban and regional development. Haloy, Essex: Logman Scientific \& Technicall, 1995.

MESQUITA, Ana Cleusa Serra; CERQUEIRA, Daiane; ALMEIDA, Paulo Henrique. A distribuição dos serviços no Brasil: uma análise a partir da PNDA e da PAS. Revista da Superintendência de Estudos Econômicos e Sociais da Bahia: Servicos Estratégicos na Região Metropolitana de Salvador, Salvador, SEI, 2004. (Série estudos e pesquisa, 70)

MORAES FILHO, Mello. Festas e tradições populares no Brasil. Belo Horizonte: Itatiaia,1979.

OLIVEIRA, Mário Mendonça. A Bahia e seus bens culturais. Revista do IPACH [S.l.], 1979.

OLIVEIRA, Roberto Cardoso de. Identidade catalã e ideologia étnica (pensamento antropológico e etnicizacão) In Caminhos da identidade: ensaios sobre etnicidade e multiculturalismo. São Paulo: Unesp; Brasília: Paralelo, 2006.

OLIVEIRA, Waldir Freitas; LIMA, Vivaldo da Costa. Cartas de Edison Carneiro a Arthur Ramos: de 04 de janeiro de 1936 a 06 de dezembro de 1938. Salvador: Currupio, 1987.

PARÉS, Luis Nicolau. História e ritual da nação Jeje na Bahia. Campinas: Unicamp, 2006.

PELOURINHO: levantamento sócio-econômico. Salvador: IPAC Superintendência de Turismo da Cidade de Salvador, abr./nov., 1967.

PINHO, Wanderley. Salões e damas do Segundo Império. São Paulo: GRD, 2004

QUEIROZ, Lúcia Aquino. Turismo na Bahia: estratégias para o desenvolvimento. Salvador: Secretaria de Cultura e Turismo, 2002.

RODRIGUES, Fernando Os ritmistas e a cidade: sobre o processo de formacão da música baiana contemporânea orientada para a diversão. 2006. Dissertação (Mestrado em Sociologia) - PGSOL da Universidade de Brasília, 2006. SACK, R.D. Place, modernity and the consumer's World. Baltimore: The Johns Hopkinks University Press, 1992.

SANTOS, Jocélio Teles. O poder da cultura e a cultura no poder: a disputa simbólica da herança cultural negra no Brasil. Salvador: EDUFBA, 2005

SANTOS, Milton.. Técnica, espaço e tempo (globalização e meio técnico-científico informacional. São Paulo: Hucitec, 1998

SCHWARZMAN, Simon et al. Nos tempos de Capanema. Rio de Janeiro: Paz e Terra, 1984. 
SILVA, Agostinho. Considerando o Quinto Império. Ensaios sobre Cultura e Literatura Portuguesa e Brasileira, Camarate,Pt: Círculo de Leitores, 2002 a, v.2.

Da existência do CEAO. Ensaios sobre Cultura e Literatura Portuguesa e Brasileira, Camarate,Pt, Círculo de Leitores, v.1, 2002b.

A cultura brasileira. Ensaios sobre Cultura e Literatura Portuguesa e Brasileira, Camarate,Pt, Círculo de Leitores, v.2, 2000c.

SILVEIRA, Renato. O Candomblé da Barroquinha: processo de constituição do primeiro terreiro baiano de Keto. Salvador: Maianga, 2006.

TAVARES, Odorico. Bahia: imagens da terra e do povo. Rio de Janeiro: Edições de Ouro, 1978.
TEIXEIRA, Tatiana. Modernismo e modernidade na Universidade da Bahia. In: RUBIM, Antônio Albino Canelas (Org.) A ousadia da criação: universidade e cultura. Salvador: UFBA/Facom, 1999.

UGHETTO, Pascal; DU TERRE, Christian. Service, espace et territoires: un aperçu de quelques problématiques de recherche. Paris: IRIS, Universite Paris IX, 2000

YELVINGTON, Kevin A. Melville J. Herskovits and the institutionalization of afro-american studies. In: O PROJETO Unesco no Brasil: uma volta crítica 50 anos depois. Salvador: UFBA/Pallas, 2007.

WALLERSTEIN, Immanuel. Culture as the ideological battleground of the modern world-system. In: MIKE Featherstone (Org.) Global culture: nationalism, globazation and modernity. London: Sage, 1990. 


\section{WHEN INNOVATING IS APPEALING TOTRADITION. THE BAHIAN CONDITION FACING TOURIST MODERNIZATION}

\author{
Edson Farias
}

The objective of this paper is to focus the role accorded to tradition as a component of a socialhistorical dynamics schemed among different groups in Salvador, but whose effect defined a way of modernization connected with the crossing of group identities, immaterial and architectural patrimonies, the transit of images and the informational capitalism. Such way of modernization defined a touristic experience marked by the uses, by the city and in the city, that are made of space, of memory and of cultural expressions, resources that are decisive and, at the same time, they revolve a land of social-symbolic contradictions that feed the symbolic economy.

KEYwords: innovation, bahian tradition, touristic modernization, services.

\section{QUAND INNOVER, C'EST FAIRE APPEL À LA TRADITION. BAHIA ET SA CONDITION FACE À LA MODERNISATION TOURISTIQUE}

\author{
Edson Farias
}

L'objectif de cet article est de cibler l'accent mis sur la tradition en tant que composante d'une dynamique socio-historique tissée entre des groupes distincts à Salvador, mais dont l'effet a été de définir un mode de modernisation lié au croisement d'identités de groupes, de patrimoines immatériels et architectoniques, aux transits d'images et au capitalisme informationnel. Un tel mode de modernisation a engendré une expérience touristique marquée par les us et coutumes, de la ville et dans la ville, qui transforment l'espace, la mémoire et les expressions culturelles en ressources décisives mais qui, en même temps, retournent un terrain parsemé de contradictions socio symboliques qui soutiennent l'économie symbolique.

Mots-CLÉs: innovation, tradition bahianaise, modernisation touristique, services.

Edson Farias - Doutor em Ciências Sociais pela Universidade de Campinas. Professor do Departamento de Sociologia da Universidade de Brasília, Integra o Núcleo de Pesquisa em Cultura, Memória e Desenvolvimento, desenvolvendo pesquisas na área de Sociologia da Cultura. Suas mais recentes publicações: Memória, Linguagem e Saber Incorporado em Norbert Elias; Sociologia e a Crítica do Contemporâneo; Tensões em um Processo Civilizador Baiano e Culturas Populares na Economia Simbólica no Brasil. 